Universidade de Brasília

Instituto de Ciências Biológicas

Departamento de Botânica

Programa de Pós-Graduação em Botânica

\title{
Brioflora da Ilha de Fernando de
}

\section{Noronha, Brasil}

\author{
Carla Gomes Pereira
}

Brasília - DF

Fevereiro de 2015 


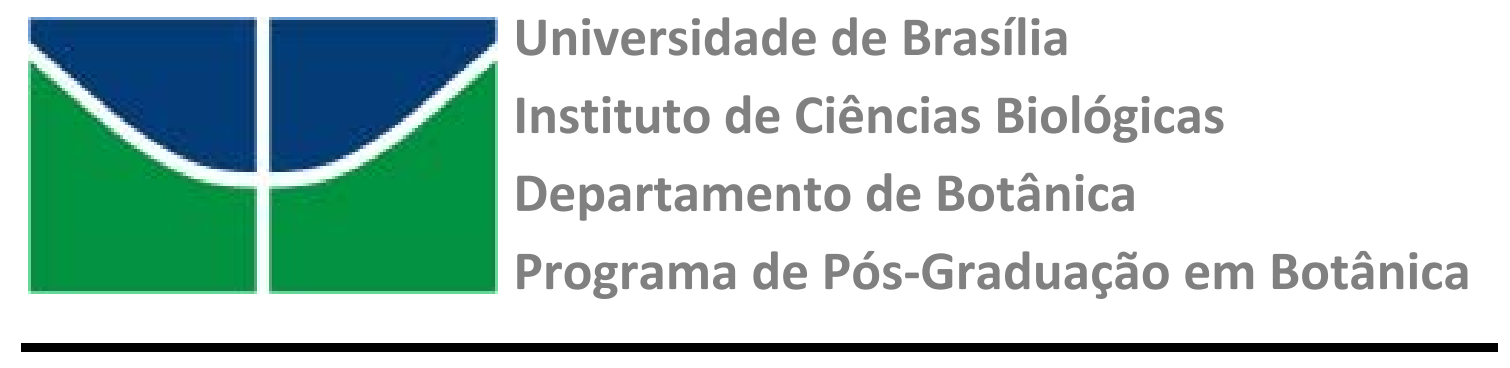

\section{Brioflora da Ilha de Fernando de Noronha, Brasil}

\section{Carla Gomes Pereira}

Dissertação apresentada ao Programa de PósGraduação em Botânica da Universidade de Brasília, como parte dos requisitos necessários para a obtenção do título de Mestre em Botânica.

Orientador: Dr. Paulo Eduardo A. S. Câmara

Brasília - DF

Fevereiro de 2015

Brioflora da Ilha de Fernando de Noronha, Brasil 


\section{Carla Gomes Pereira}

Dissertação apresentada ao Programa de Pós-Graduação em Botânica da Universidade de Brasília, como parte dos requisitos necessários para a obtenção do título de Mestre em Botânica.

Aprovada em:

Dr. Paulo Eduardo Aguiar Saraiva Câmara

(Orientador)

Universidade de Brasília

Dra. Nívea Dias dos Santos

(Membro externo)

Universidade Federal de Pernambuco

Dra. Maria das Graças Machado de Souza

Universidade de Brasília

Dra. Carolyn Elinore Barnes Proença

(Suplente)

Universidade de Brasília

Brasília - DF

Fevereiro de 2015 
Com imensa gratidão, à minha família, principalmente Robson e Jeferson, que tem me apoiado em minhas escolhas.

Dedico 


\section{Agradecimentos}

À minha família, por compreender a minha dedicação a esse trabalho. Ao meu esposo, Robson por me ouvir e me apoiar nas minhas escolhas e ao meu filho por aceitar as minhas faltas.

Ao professor Dr. Paulo Câmara, pela orientação, pela oportunidade de realizar esse trabalho e pela ajuda nas coletas. Pela amizade, dedicação e momentos de descontração. À sua esposa, Dr. Micheline Carvalho Silva pela também amizade, coorientação extra-oficial, pelas diversas contribuições e agradável participação nas coletas.

Aos colegas do laboratório, que me ajudaram com as identificações das plantas, por discutir e debater os termos botânicos, que no momento, me eram novos. Aos que me ensinaram e me ajudaram a identificar as briófitas. Àqueles que participaram e me ajudaram nos esclarecimentos das dúvidas e nas escolhas do melhor caminho para resolução dos problemas no decorrer do curso.

Especialmente à Dr. Graça Machado, professora notável que sempre me apoiou e me ajudou a despertar o amor pela ciência sem deixar de lado a didática.

À Dr. Nívea por suas enormes contribuições, por me receber em sua casa e me acompanhar por uma semana em uma das expedições, por colaborar com parte de seus conhecimentos e práticas de campo além de me ceder o seu tempo.

Ao Dr. Denilson Peralta por me receber muito bem no Herbário SP, ceder o laboratório e sua colaboração.

À Dra. Juçara Bordin pela sua enorme contribuição na confirmação das espécies de Fissidentaceae.

Às Dras. Carol, Regina e Sueli e ao Dr. Diego Knop pelas revisões, correções e grandes contribuições do texto.

À Administração do Arquipélago de Fernando de Noronha por me autorizar a entrar e coletar as amostras que precisava para o levantamento. Ao Sr. Alexandre José 
pela colaboração. Ao Sr. Daniel pela presteza nos esclarecimentos burocráticos e por nos apresentar a ilha.

A toda equipe do IBAMA e do ICMBio do Arquipélago de Fernando de Noronha, que nos receberam com muita gentileza e agilidade. Ao Sr. Eduardo pelas ricas informações e por nos conduzir numa difícil saída de campo. Ao Sr. Ricardo pela colaboração e liberação do Sr. Policarpo. Ao Sr. Policarpo pelo carinho e disposição para nos acompanhar por alguns dias. E também à Sra. Claudiane, Sra. Viviane, Sr. Ricardo e Sr. Luiz Antonio pela atenção. Ao Sr. Sinval por nos guiar com ânimo e disposição.

À Débora e Mayara, voluntárias do Projeto Tamar, por suas contribuições e informações.

Aos colegas do Herbário UB que contribuíram de alguma forma para o desenvolvimento desse trabalho. Principalmente à Josemília, por me ajudar com sistema de informação do herbário, BRAHMS.

À engenheira florestal Luiza Lenzi, que me ajudou na montagem do mapa.

Ao CNPq pela concessão da bolsa de Mestrado do Programa de Pós-Graduação. Ao Programa de Pós-Graduação da Universidade de Brasília, pelo apoio a realização do curso e apoio financeiro. À Finatec pelo apoio financeiro para participação em congresso. 
“Sonhar é importante, mas o sonho é apenas o combustível do motor das realizações.

Sonho sem atitude é delírio."

(Carlos Hilsdorf) 
Sumário

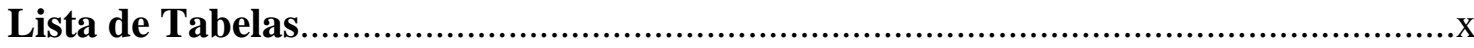

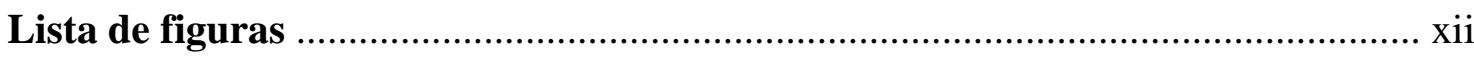

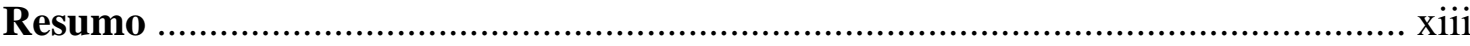

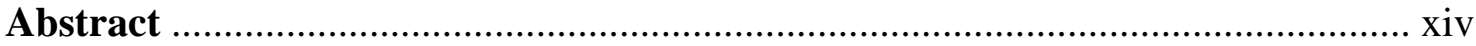

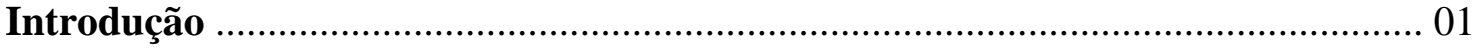

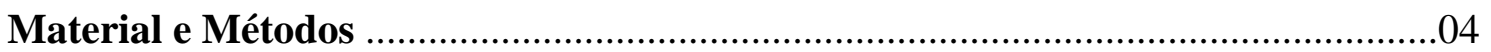

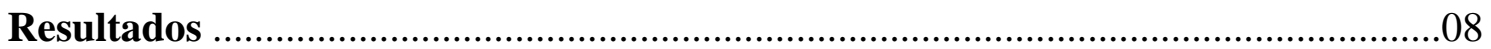

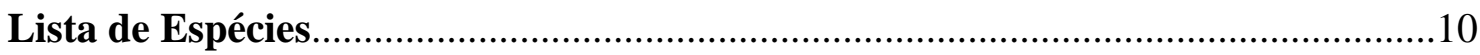

Tratamento taxonômico para Anthocerotophyta.................................................11

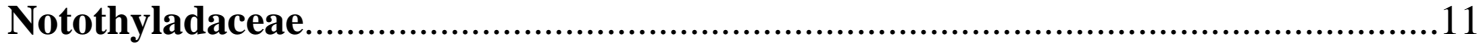

Notothylas breutelii (Gottsche) Gottsche...................................................................11

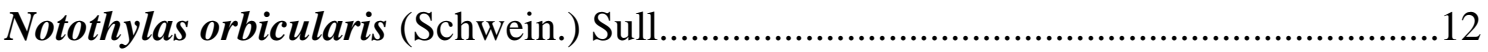

Tratamento taxonômico para Marchantiophyta.....................................................13

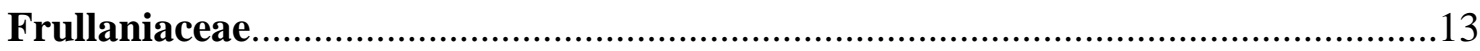

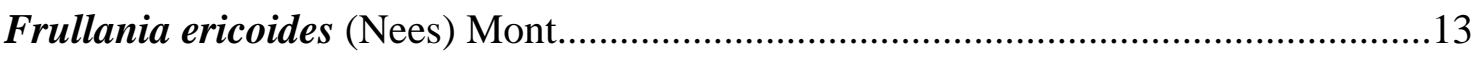

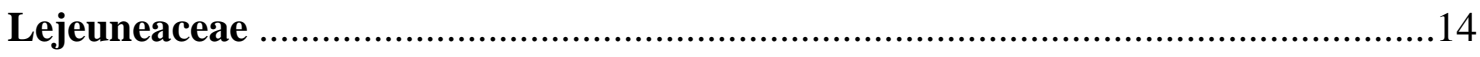

Lejeunea laetevirens Nees \& Mont.............................................................................14

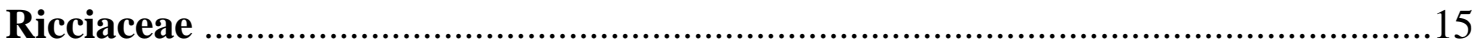

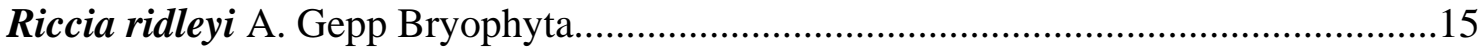

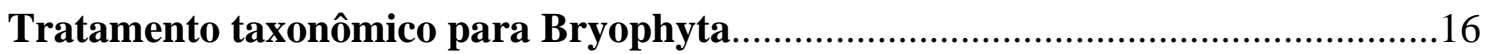

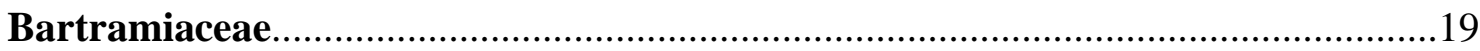

Philonotis cernua (Wilson) D.G. Griffin \& W.R. Buck ..........................................19

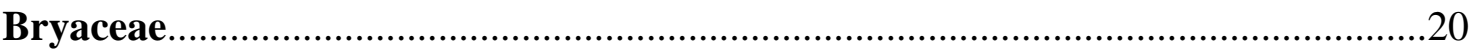

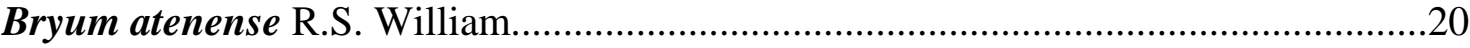

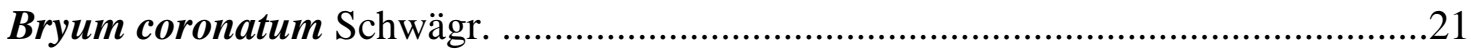

Gemmabryum apiculatum (Schwägr.) J.R. Spence \& H.P. Ramsay.............................22

Gemmabryum subapiculatum (Hampe) J.R. Spence \& H.P. Ramsay............................23

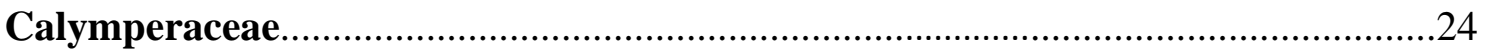

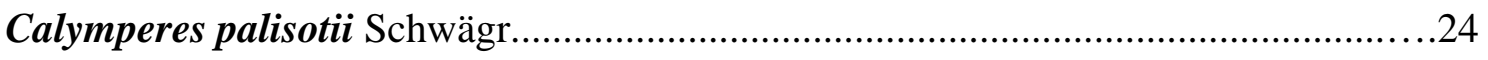

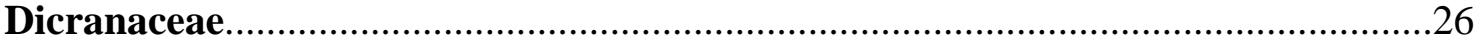

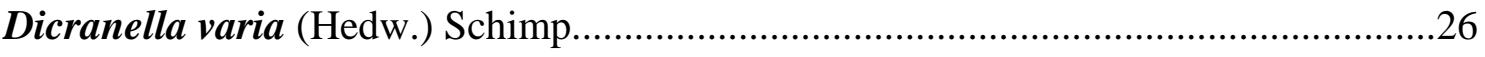

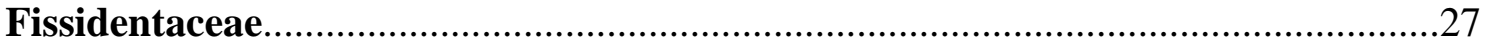




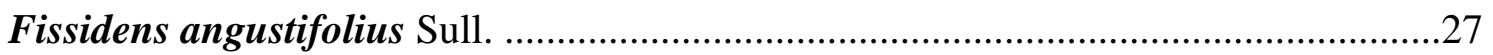

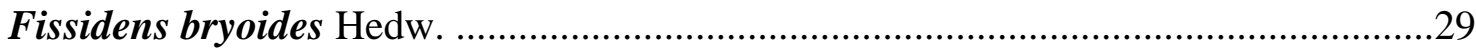

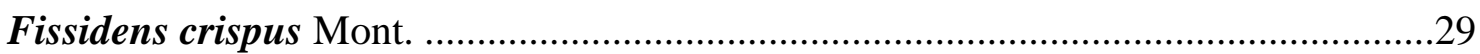

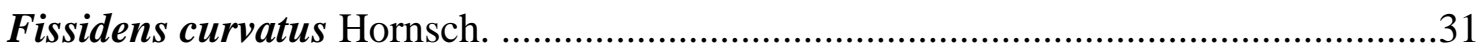

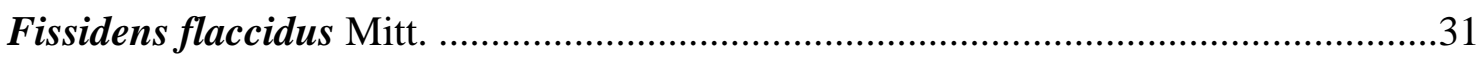

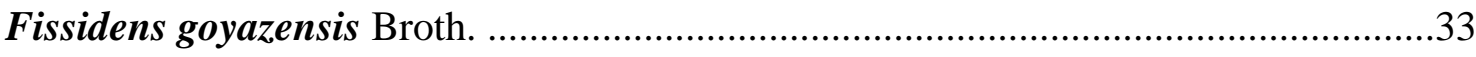

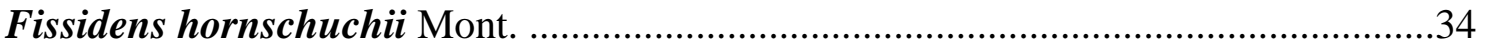

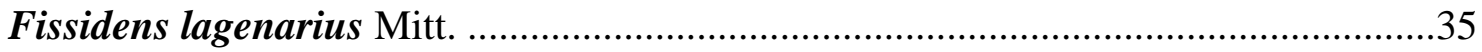

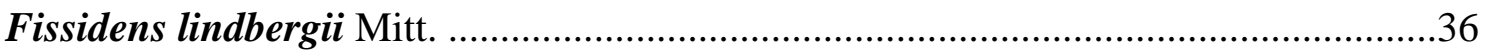

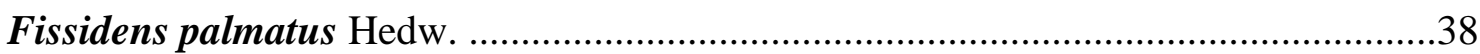

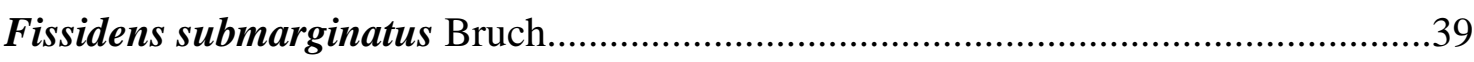

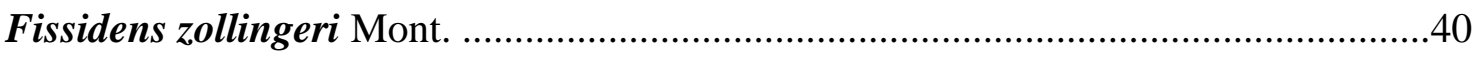

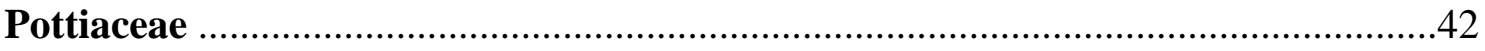

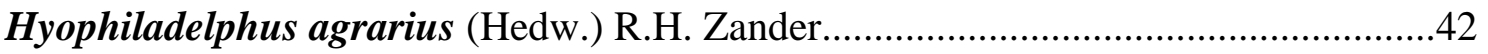

Plaubelia sprengelii (Schwägr.) R.H. Zander...........................................................42

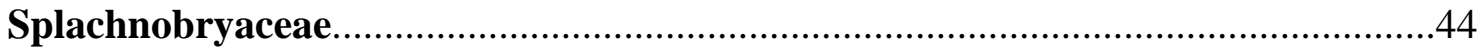

Splachnobryum obtusum (Brid.) Müll. Hal. ..............................................................43

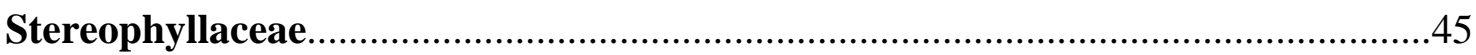

Entodontopsis leucostega (Brid.) Buck \& Ireland ...................................................44

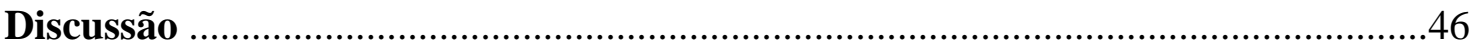

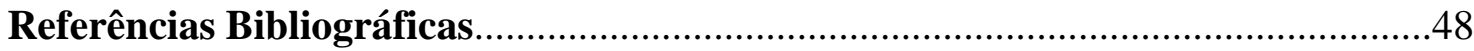




\section{Lista de Tabelas}

Tabela 1: Síntese das expedições realizadas em Fernando de Noronha, seus respectivos coletores, período de coletas e número de coletas.........................................................05

Tabela 2: Representatividade das famílias identificadas na Ilha de Fernando de

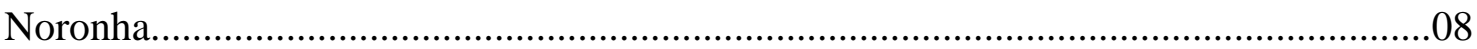




\section{Lista de Figuras}

Figura 1: Mapa mostrando a localização do Arquipélago de Fernando de Noronha no mapa do Brasil e todos os pontos de coleta. .06

Figura 2: Notothylas breutelii (Gottsche) Gottsche, A- Visão geral do gametófito; B e C- Esporos e D- Pseudo-elatérios globosos (D.M. Vital 8341). Escalas: A e B = 200 $\mu$; $\mathrm{C}$ e $\mathrm{D}=50 \mu \mathrm{m}$. .12

Figura 3: Notothylas orbicularis (Schwein.) Sull., A e B- Visão geral do gametófito e C- Esporos. (D.M. Vital 8326) Escalas: A e B = 500 $\mu \mathrm{m}$; C e D = 50 $\mu \mathrm{m}$. 13

Figura 4: Riccia ridleyi A. Gepp. A- Margem do talo com bordas de cor violeta (seta) e B- Talo (Pereira et al. 241). Escala: $B=500 \mu \mathrm{m}$. .16

Figura 5: Philonotis cernua (Wilson) D.G. Griffin \& W.R. Buck, A- Visão geral do gametófito; B- Filídio; C- Ápice do filídio; D- Células da lamina do filídio (Pereira et al. 273). Escalas: $\mathrm{A}=200 \mu \mathrm{m} ; \mathrm{B}=100 \mu \mathrm{m} ; \mathrm{C}$ e $\mathrm{D}=10 \mu \mathrm{m}$ .19

Figura 6: A- Filídio de Gemmabryum apiculatum (Schwägr.) J.R. Spence \& H.P. Ramsay. (Pereira et al. 106); (B-C)- Bryum atenense R.S. Williams, B- Filídio; CVisão geral do gametófito (Pereira et al. 453); D- Filídio de Gemmabryum subapiculatum (Hampe) J.R. Spence \& H.P. Ramsay (Pereira et al. 29). Escalas: A-D = $100 \mu \mathrm{m}$

Figura 7: Dicranella varia (Hedw.) Schimp., A- Visão geral do gametófito; B- Filídio; C- Ápice agudo do filídio mostrando margem levemente denticulada; D- Base do filídio (Pereira et al. 292). Escalas: $\mathrm{A}=200 \mu \mathrm{m} ; \mathrm{B}=100 \mu \mathrm{m}$ e $\mathrm{D}=50 \mu \mathrm{m}$. .26

Figura 8: Fissidens angustifolius Sull., A- Visão geral do gametófito; B- Filídio; CÁpice do filídio; D-; Células da região mediana do filídio; E- Caulídio mostrando nódulos axilares hialinos (Pereira et al. 222). Escalas: A = 100 $\mu \mathrm{m}$; B $=50 \mu \mathrm{m}$; C, D e E $=10 \mu \mathrm{m}$ .28 
Figura 9: Fissidens crispus Mont., A- Visão geral do gametófito; B- Filídio; C- Ápice do filídio mostrando células organizadas em fileiras distintas; D- Base do filídio (Pereira et al. 86). Escalas: A, B e D = 100 $\mu \mathrm{m} ; \mathrm{C}=10 \mu \mathrm{m}$. .30

Figura 10: Fissidens curvatus Hornsch., A- Visão geral do gametófito; B- Filídio com detalhe do limbídio biestratoso (O. Yano \& D.P. Costa 13631); (C-E) Fissidens flaccidus Mitt., C- Visão geral do gametófito; D- Gemas clavadas (setas) presentes no

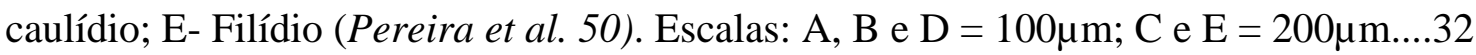

Figura 11: Fissidens lagenarius Mitt., J. Linn, A- Visão geral do gametófito; B- Ápice do filídio mostrando costa sub-percurrente; C- Filídio mostrando limbídio na lâmina vaginante; D- Células da região mediana do filídio (Pereira et al. 57). Escalas: A = $100 \mu \mathrm{m} ; \mathrm{B}$, C e D = $10 \mu \mathrm{m}$ .35

Figura 12: Fissidens lindbergii Mitt., A- Visão geral do gametófito; B- Filídio; CÁpice do filídio; D- Base do filídio mostrando células retangulares; E- Células da região mediana do filídio (Pereira et al. 361). Escalas: A, B, C e D = 100 $\mu \mathrm{m} ; \mathrm{E}=10 \mu \mathrm{m} . . . . . .37$

Figura 13: Fissidens submarginatus Bruch in Kraus, A- Visão geral do gametófito; BFilídio mostrando limbídio na lâmina vaginante; C- Ápice do filídio mostrando margem crenulada e costa percurrente; D- Base do filídio (D.M. Vital 8338). Escalas: A = $200 \mu \mathrm{m} ; \mathrm{B}$ e $\mathrm{D}=100 \mu \mathrm{m} ; \mathrm{C}=50 \mu \mathrm{m}$.

Figura 14: Fissidens zollingeri Mont., A- Visão geral do gametófito; B e C- Caulídio com nódulos axilares hialinos evidentes; D- Filídio; E- Ápice do filídio mostrando o limbídio confluente com o ápice e F- Base do filídio (Pereira et al. 112). Escalas: A e C $=100 \mu \mathrm{m} ; \mathrm{B}, \mathrm{E}$ e $\mathrm{F}=10 \mu \mathrm{m}$

Figura 15: Entodontopsis leucostega (Brid.) Buck \& Ireland, A- Visão geral de parte do gametófito pleurocárpico; B- Filídio. C- Células da lâmina do filídio longo-hexagonais; D- Base do filídio irregular entre os lados da costa; E- Esporófito (Pereira et al. 144). Escalas: $\mathrm{A}=200 \mu \mathrm{m} ; \mathrm{B}, \mathrm{D}$ e $\mathrm{E}=100 \mu \mathrm{m} ; \mathrm{C}=10 \mu \mathrm{m}$. .45 


\section{Brioflora da Ilha de Fernando de Noronha, Brasil}

\section{Resumo}

O arquipélago Fernando de Noronha é constituído por um grupo de 21 ilhas oceânicas, de natureza vulcânica, localizado a uma distância de 350 km de Natal, RN e 545 km de Recife, PE. O conjunto de ilhas ocupa uma área total de $26 \mathrm{~km}^{2}$ e a principal ilha, Fernando de Noronha, tem aproximadamente 18,4 km². Embora existam vários estudos relacionados à vegetação das ilhas, apenas dois são relacionados à brioflora. Um realizado em 1891, e outro, cem anos depois. O objetivo desse trabalho foi realizar um novo inventário da brioflora da ilha de Fernando de Noronha, acrescentando chaves, ilustrações e comentários bem como verificar se os táxons levantados anteriormente ainda permanecem na ilha 35 anos após o último inventário. Como metodologia foi realizada uma visita ao Herbário SP, onde 116 exsicatas foram reanalisadas, e duas expedições ao arquipélago, resultando em 475 novas amostras coletadas. Como resultado, foram identificadas 28 espécies de briófitas: sendo duas da Divisão Anthocerothophyta (Notothyladaceae); três da Divisão Marchantiophyta, dividias em três famílias e 23 espécies da Divisão Bryophyta, distribuídas em oito famílias, sendo a família Fissidentaceae, com 12 espécies, a mais diversa. Onze espécies são novas citações para a ilha. Cinco espécies anteriormente identificadas, não foram encontradas nem em herbário nem em campo. Seis espécies são consideradas raras em Noronha. 


\section{Bryoflora of Fernando de Noronha Island, Brazil}

\section{Abstract}

The archipelago of Fernando de Noronha consists of a group of 21 oceanic islands of volcanic origin, located at a distance of $350 \mathrm{~km}$ from Natal, RN and $545 \mathrm{~km}$ of Recife, PE. The group of islands has a total area of $26 \mathrm{~km}^{2}$ and the main island, Fernando de Noronha, has approximately $18,4 \mathrm{~km}^{2}$. Even though several studies on the vegetation of the islands exist, only two are related to bryophytes. One realized in 1891 and another one hundred years later. The objective of this study was to update a new inventory of bryophytes of Fernando de Noronha, adding keys, figures and comment, as well as verify if the taxa previously collected still remains on the island 35 years after the last survey. The methodology included a visit to the herbarium SP, where 116 vouchers were re-examined, and two expeditions to the archipelago with 475 new samples collected. As a result, we identified 28 species of bryophytes: two from Anthocerothophyta Division (Notothyladaceae); three Marchantiophyta Division, from three different families and 23 species of Bryophyta Division distributed in eight families, being the Fissidentaceae, with 12 species, the most diverse. Eleven species are new records for the island. Five species previously identified, were not found either in the herbarium or the field. Six species are considered rare in Noronha. 


\section{Introdução}

O arquipélago de Fernando de Noronha é um conjunto de ilhas oceânicas brasileiras situadas no oceano Atlântico Sul equatorial, pertencente ao estado de Pernambuco, localizado a $3^{\circ} 51^{\prime} \mathrm{S}$ e $32^{\circ} 2^{\prime}$ W a uma distância de $350 \mathrm{~km}$ de Natal, Rio Grande do Norte e 545 km de Recife, Pernambuco (Almeida et al. 2002; Castro 2009). Constitui um grupo de 21 ilhas, ilhotas ou rochedos e lajedos, todas de natureza vulcânica. A principal e maior delas é chamada de Ilha de Fernando de Noronha (Almeida 1955) (Fig. 1).

O conjunto de ilhas ocupa uma área total de $26 \mathrm{~km}^{2}$ com altitude de 4.000 metros a partir do fundo do mar. A ilha de Fernando de Noronha tem aproximadamente 18,4 $\mathrm{km}^{2}$ e é formada por rochas vulcânicas e relevo irregular (Almeida et al. 2002; Castro 2009). O ponto mais alto do arquipélago é chamado de “Morro do Pico” com 321 metros de altitude acima do nível do mar, localizado na região central da ilha Fernando de Noronha (Almeida 1955).

O primeiro a visitar e relatar o arquipélago foi Américo Vespúcio no ano de 1503, por meio da quarta expedição exploratória ao litoral brasileiro comandada por Gonçalo Coelho. Vespúcio diz que um dos seis navios utilizados na viagem naufragou e a tripulação utilizou a ilha para abrigo e reabastecimento (Gepp et al. 1891; Markham 2005). Porém, em 1502, Fernando de Noronha já havia sido representado com o nome de Quaresma em um mapa do Brasil considerado o mais antigo. Em 1504 o arquipélago foi doado a Fernão de Loronha e a partir daí, apesar das suas várias mudanças de nome, passou a ser chamado de Fernando de Noronha (Teixeira et al. 2003).

Nos relatos de Américo Vespúcio, em 1503, a vegetação da ilha foi descrita como “um boníssimo porto”, com “numerosas árvores infinitas” e água doce. Em 1832, na expedição do "HMS Beagle”, Charles Darwin visitou a ilha, promoveu as primeiras coletas botânicas e mencionou que ela era coberta por árvores. Contudo, foi na expedição organizada pela equipe de Ridley em 1890, que coletas e descrições científicas da vegetação foram registradas. Neste trabalho, os autores relatam que na ilha havia o predomínio de vegetação herbácea, pois as árvores de grande porte eram cortadas para evitar a construção de jangadas que facilitariam fugas de presos. 
A ocupação humana iniciou-se com apropriações temporárias por holandeses em 1629 e franceses em 1735. Tornando-se definitiva no ano de 1737, quando Portugal transformou a ilha em colônia correcional de presos comuns. O sistema prisional da ilha permaneceu por 201 anos (Teixeira et al. 2003). Durante esse período a ilha passou por intensa transformação antrópica, como a construção da Vila dos Remédios, a construção de dez fortes, o corte das árvores de grande porte e a introdução de espécies exóticas. De 1938 até 1987 a ilha esteve sob administração militar, funcionando como presídio político da União e como posto avançado de defesa durante a Segunda Guerra Mundial, quando chegou a abrigar cerca de 3 mil militares. Somente em 1988, o arquipélago foi reintegrado ao Estado de Pernambuco, transformando-se em um Distrito Estadual (Teixeira et al. 2003; Mitraud et al. 2001). Após esse período, a população continuou a crescer e o potencial ambiental do arquipélago foi reconhecido (Teixeira et al. 2003). Foram criadas duas Unidades de Conservação Federais. A primeira foi instituída em 1986, denominada Área de Proteção Ambiental de Fernando de Noronha (APA-FN) e a segunda em 1988, denominada Parque Nacional Marinho de Fernando de Noronha (PARNAMAR-FN). Ambas atualmente subordinadas ao Instituto Chico Mendes de Conservação da Biodiversidade (ICMBio) (Silva Júnior 2003).

A principal atividade econômica da ilha é o turismo (Teixeira et al. 2003). O crescimento de atividades de ecoturismo favoreceu o aumento da circulação de pessoas na ilha desde a criação do PARNAMAR- FN. No ano de 2002 foi contabilizada a entrada de mais de 62 mil visitantes em Fernando de Noronha (Silva Júnior 2003), sendo que, segundo os dados do Censo Demográfico do Instituto Brasileiro de Geografia e Estatística, em 2010 o número de habitantes era de 2.630 (IBGE 2010).

O clima é tropical, do tipo Aw do sistema de classificação Köppen (Köppen 1918), com temperatura anual média de $26,5{ }^{\circ} \mathrm{C}$ (Abdala 2008). A pluviosidade anual tem uma média de 1350 mm por ano. Essas precipitações estão distribuídas em duas estações anuais bem definidas, uma estação chuvosa no período de março a maio e uma estação seca no período de agosto a janeiro (Montenegro et al. 2009).

A rede hídrica da ilha de Fernando de Noronha é abastecida, prioritariamente, por fontes artificiais formadas por sistemas de produção de água potável. O principal sistema é o dessalinizador marinho, depois o manancial açude do Xaréu e placas de 
captação de água pluvial e, com menor capacidade, o sistema de poços tubulares (Tavares et al. 2009).

A flora fanerogâmica do arquipélago, incluindo as exóticas, é composta por cerca de 450 espécies (Batistella 1993). Segundo Pessenda et al. (2005), numerosas espécies foram introduzidas nos últimos 400 anos, resultando na modificação do ecossistema terrestre original.

De acordo com Abdala et al. (2008) três espécies representantes da flora de Noronha são endêmicas, Combretum rupicola Ridl. (Combretaceae), Ficus noronhae Oliv. (Moraceae) e Cereus insularis Hemsl. (Cactaceae). Também são registrados endemismos de espécies de animais, como peixes, aves e lagartos. De forma geral, a vegetação da ilha é caracterizada por Mata Seca e vestígios de Mata Atlântica insular, onde se encontra o único manguezal insular do Atlântico Sul, o Mangue do Sueste (ICMBio 2013). A flora de Noronha tem sido considerada semelhante à caatinga, com predomínio de plantas espinhosas e cactos de 2 a 5 m. de altura (Vital et al. 1991), presença de gramíneas, de espécies arbustivas de pequeno porte, bem como de áreas florestais alteradas (Gouveia et al. 2005).

O grupo das Briófitas, no sentido amplo, é composto pelas divisões Anthocerothophyta (Antóceros), Marchantiophyta (Hepáticas) e Bryophyta (Musgos) (Goffinet \& Shaw 2009). São plantas de pequeno porte, avasculares e morfologicamente simples na escala evolutiva. Apresentam como característica singular o gametófito dominante e de vida livre. É um grupo bastante diverso, com cerca de 25 mil espécies, representando o segundo maior grupo de plantas e podem habitar os mais diversos ambientes (Costa et al. 2010), com algumas espécies sendo definidas como organismos extremófilos, por sua capacidade de se desenvolver em ambientes extremamente secos ou frios (Gradstein et al. 2001; Shaw 2009). Além disso, por formar tapetes, as briófitas servem como substrato para o desenvolvimento de cianobactérias, algas, fungos, animais e outras plantas (Fernández \& Serrano 2009, Gradstein et al. 2001). Apresenta valor cultural e econômica para usos ornamentais. Demonstra propriedades medicinais, com estudos que comprovam atividades antimicrobiana (antifúngica, antibióticas e antivirais), anticancerígena, anti-inflamatória, antialergênica, além de atividades alelopáticas (Asakawa 2007, Fernández \& Serrano 2009). 
O primeiro levantamento da brioflora do Arquipélago de Fernando de Noronha foi realizado por Gepp et al. (1891). Em sua pesquisa foi citada uma espécie, Calymperes palisotii Schwägr., dois gêneros de musgos, Tortula Hedw. e Hypnum Hedw., e apenas uma espécie de hepática (nova para a ciência), Riccia ridleyi A. Gepp.

O segundo levantamento foi realizado cem anos depois por Vital et al. (1991), com 22 táxons listados, sendo dois de antóceros: Notothylas breutelii (Gottsche) Gottschee e Notothylas vitalii Udar \& D. K. Singh; três de hepáticas: Frullania ericoides (Nees) Mont, Lejeunea laetevirens Nees \& Mont., Riccia L.; e dezessete táxons de musgos: Bryum coronatum Schwägr., Pohlia Hedw., Calymperes palisotii, Fissidens bryoides Hedw., F. elegans Brid., F. hornschuchii Mont., F. submarginatus Bruch, F. microcladus var. pussillissimus (Steere) R. A. Pursell, F. palmatus Hedw., F. goyazensis Broth, F. zollingeri Mont., Octoblepharum albidum Hedw., Hyophiladelphus agrarius (Hedw.) R. H. Zander., Plaubelia sprengelii (Schwägr.) R. H. Zander, Splachnobryum obtusum (Brid.) Müll. Hal. e Entodontopsis leucostega (Brid.) W. R. Buck \& Ireland. Tortula Hedw. e Hypnum Hedw. não foram citados no segundo levantamento.

Tanto no primeiro quanto no segundo levantamento não foi feito um tratamento taxonômico com chaves, ilustrações e comentários da brioflora de Fernando de Noronha, nem tão pouco informações a respeito do estado de conservação das espécies.

Esse trabalho tem como objetivo realizar um novo inventário da brioflora da Ilha de Fernando de Noronha, com chaves, ilustrações e comentários, bem como verificar se as espécies encontradas por Vital et al. (1991) ainda permanecem na ilha 35 anos após a última coleta. Com isso, contribuir para o monitoramento e preservação da brioflora após a criação das Unidades de Conservação Ambiental (UC) de Fernando de Noronha.

\section{Material e métodos}

Foi feita uma visita ao herbário do Instituto de Botânica de São Paulo (SP) em setembro de 2013 onde foram analisadas 115 exsicatas de briófitas de Fernando de Noronha, coletadas por Daniel Vital em 1978, (39 amostras feitas em seis dias), e também as coletas de Olga Yano \& Denise Pinheiro da Costa feitas em 1989, (76 
amostras feitas em 20 dias). Todas as amostras foram analisadas e reidentificadas, observando-se as informações contidas nos envelopes. A partir disso, delimitaram-se as áreas de coletas na tentativa de reproduzir o máximo possível as mesmas rotas das coletas anteriores, bem como explorar as áreas que ainda não haviam sido coletadas.

Foram então realizadas duas expedições à ilha, com duração média de nove dias cada, a primeira em novembro de 2013, período de seca, com 180 amostras coletadas, e a segunda em maio de 2014, período de chuvas, onde 295 amostras foram coletadas. No total foram coletadas 475 amostras nas duas expedições (Tabela 1) em aproximadamente 70 pontos de coleta (Figura 1).

Tabela 3: Síntese das expedições realizadas em Fernando de Noronha, seus respectivos coletores, período de coletas e número de coletas.

\begin{tabular}{|c|c|c|c|c|c|c|}
\hline & ATA & COLETOR & PERÍODO & COLETAS & \multicolumn{2}{|c|}{ TOTAL } \\
\hline \multirow{2}{*}{ 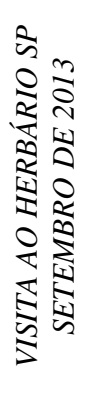 } & JULHO DE 1978 & DANIEL VITAL & 6 DIAS & 39 AMOSTRAS & \multirow{2}{*}{ 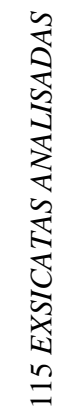 } & \\
\hline & $\begin{array}{c}\text { NOVEMBRO DE } \\
1989\end{array}$ & OLGA E DENISE & 20 DIAS & 76 AMOSTRAS & & \\
\hline 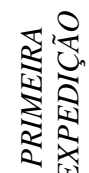 & $\begin{array}{c}\text { NOVEMBRO DE } \\
2013 \text { (SECA) }\end{array}$ & $\begin{array}{c}\text { CARLA, } \\
\text { MICHELINE E } \\
\text { PAULO }\end{array}$ & 8 DIAS & $\begin{array}{c}180 \\
\text { AMOSTRAS }\end{array}$ & \multirow{2}{*}{ 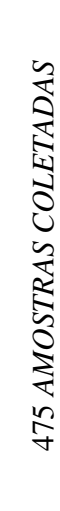 } & \\
\hline 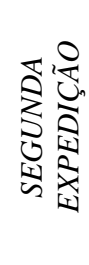 & $\begin{array}{l}\text { MAIO DE } 2014 \\
\text { (CHUVOSA) }\end{array}$ & CARLA E NÍVEA & 9 DIAS & $\begin{array}{c}295 \\
\text { AMOSTRAS }\end{array}$ & & 590 \\
\hline
\end{tabular}




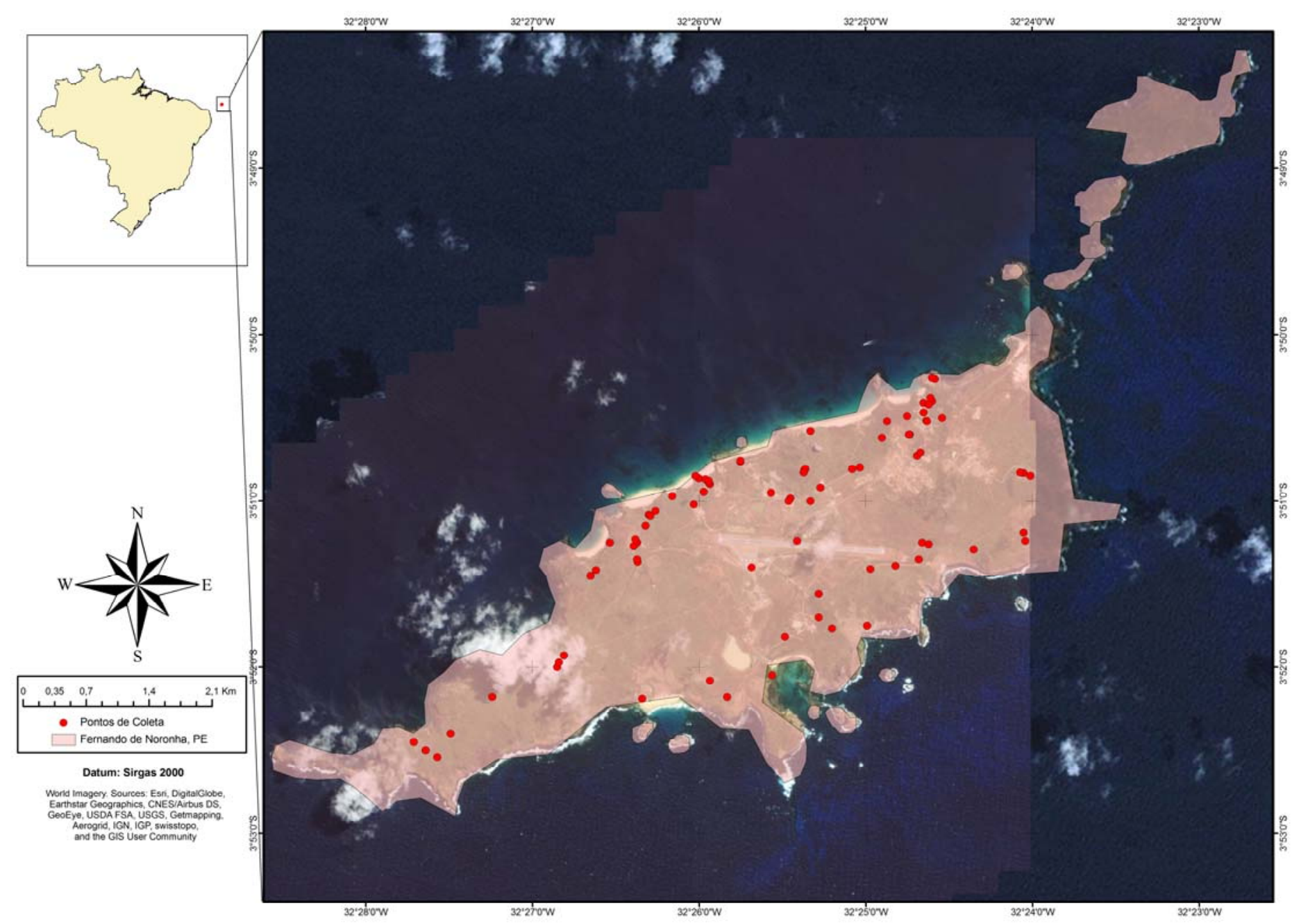

Figura 1: Mapa mostrando a localização do Arquipélago de Fernando de Noronha com relação ao Brasil e os pontos de coleta realizados nas expedições de 2013 e 2014. 
As briófitas foram coletadas segundo a metodologia de Yano (1984). Ou seja, coletadas manualmente, juntamente com parte do substrato ou com o auxílio de um canivete ou espátula e acondicionadas em sacos de papel pardo devidamente identificado com dados referentes ao local, data, tipo de substrato e ecossistema. As identificações das plantas foram feitas através de literatura especializada e depois depositadas no herbário da Universidade de Brasília (UB).

Os sistemas de classificação adotados para as identificações das plantas foram baseados em Renzaglia \& Vaughn (2009) para antóceros, Crandall-Stotler et al. (2009) para hepáticas e Goffinet et al. (2009) para musgos. A distribuição geográfica foi baseada em Costa et al. (2011) e na Lista de Espécies da Flora do Brasil (http://floradobrasil.jbrj.gov.br/).

Para o tratamento taxonômico foi utilizado microscópio estereoscópico (lupa), marca: Nikon, modelo: SMZ445, nos aumentos de 0,8 a 3,5 vezes; microscópio óptico marca: Nikon, modelo: Eclipse E200, nos aumentos de 4, 10 e 40 vezes e chaves de identificação. Os aspectos gerais, como gametófito, caulídio, filídio e esporófito de cada amostra, foram analisados a partir da reidratação e montagem em lâminas semipermanentes com solução de Hoyer (Anderson 1954). As figuras dos táxons foram montadas com imagens apenas das espécies que são novas citações para a Ilha. Duplicatas foram enviadas ao herbário do Instituto de Botânica de São Paulo (SP).

Os termos morfológicos utilizados para a montagem das chaves, aqui apresentadas, foram baseados na Versão Brasileira do Glossarium Polyglottum Bryologiae (Luizi-Ponzo et al. 2006).

Os critérios utilizados para definir a raridade de uma espécie foram adotados com base na freqüência de ocorrência das espécies (Schumacker 1985) em cada ponto de coleta. Segundo (Virtanen 2014) as freqüências de ocorrência local e global de briófitas não são necessariamente similares, visto que os fatores que determinam a dinâmica de distribuição estão ligados ao grau de limitação de dispersão. Com isso, considerando que o Arquipélago é isolado geograficamente, optou-se por denominar como espécie rara aquelas que foram encontradas em apenas um ou dois pontos de coleta na Ilha de Fernando de Noronha. 


\section{Resultados}

Um total de 590 exsicatas foi analisado. Deste, 115 amostras estavam depositadas no Instituto de Botânica de São Paulo (SP) e 475 amostras foram coletadas durante as expedições de 2013 e 2014. Foram identificadas 28 espécies de briófitas, sendo que duas são da Divisão Anthocerothophyta, representada pela família Notothyladaceae; três são de Marchantiophyta, representadas pelas famílias Frullaniacea, Lejeuneaceae e Ricciaceae e 23 espécies são de Bryophyta, distribuídas em oito famílias (Tabela 2). A família mais representativa dentre os musgos foi a Fissidentaceae, com 11 espécies. As espécies com o maior número de ocorrência na ilha são Calymperes palisotii Schwägr. e Entodontopsis leucostega (Brid.) Buck \& Ireland, o único musgo pleurocárpico registrado.

Onze espécies são novas citações para a ilha (Bryum atenense R.S. Williams, Fissidens angustifolius Sull., F. crispus Mont., F. curvatus Hornsch., F. flaccidus Mitt., F. lagenarius Mitt., F. lindbergii Mitt., Gemmabryum apiculatum (Schwägr.) J.R. Spence \& H.P. Ramsay, G. subapiculatum (Hampe) J.R. Spence \& H.P. Ramsay, Notothylas orbicularis (Schwein.) Sull. e Philonotis cernua (Wilson) D.G. Griffin \& W.R. Buck). Outros cinco táxons, anteriormente citadas por Vital et al. (1991), não foram encontradas no herbário SP e nem nas novas coletas de 2013 e 2014. São elas: Fissidens elegans, F. microcladus var. pussillissimus, Notothylas vitalii, Octoblepharum albidum e Pohlia sp.

Além disso, seis espécies foram consideradas raras, ou seja, com uma ou duas ocorrências em pontos distintos, como é caso de Bryum atenense, Dicranella varia, Fissidens curvatus, F. lagenarius, F. submarginatus e Philonotis cernua.

Tabela 4: Representatividade das famílias identificadas na Ilha de Fernando de Noronha.

\begin{tabular}{lll}
\hline 02 & Anthocerothophyta & $\begin{array}{l}\text { 01 família } \\
\text { (Notothyladaceae) }\end{array}$ \\
\hline 03 & Marchantiophyta & $\begin{array}{l}\text { 03 famílias } \\
\text { (Jubulaceae, Lejeuneaceae e Ricciaceae) }\end{array}$ \\
\hline 23 & Bryophyta & $\begin{array}{l}08 \text { famílias } \\
\text { (Bartramiaceae, Bryaceae, Calymperaceae, } \\
\end{array}$ \\
& & $\begin{array}{l}\text { Dicranaceae, Fissidentaceae, Pottiaceae, } \\
\text { Splachnobryaceae, Stereophyllaceae) }\end{array}$ \\
\hline
\end{tabular}




\section{Lista de espécies}

\section{Anthocerotophyta}

Notothyladaceae

Notothylas breutelii (Gottsche) Gottsche

Notothylas orbicularis (Schwein.) Sull.*

\section{Marchantiophyta}

Frullaniaceae

Frullania ericoides (Nees ex Mart.) Mont.

Lejeuneaceae

Lejeunea laetevirens Nees \& Mont.

Ricciaceae

Riccia ridleyi A. Gepp

\section{Bryophyta}

Bartramiaceae

Philonotis cernua (Wilson) D.G. Griffin \& W.R. Buck*

Bryaceae

Bryum atenense R.S. Williams*

Bryum coronatum Schwägr.

Gemmabryum apiculatum (Schwägr.) J.R. Spence \& H.P. Ramsay*

Gemmabryum subapiculatum (Hampe) J.R. Spence \& H.P. Ramsay*

$$
\text { Calymperaceae }
$$

Calymperes palisotii Schwägr.

Dicranaceae

Dicranella varia (Hedw.) Schimp. 
Fissidentaceae

Fissidens angustifolius Sull.*

Fissidens bryoides Hedw.

Fissidens crispus Mont.*

Fissidens curvatus Hornsch.*

Fissidens flaccidus Mitt.*

Fissidens goyazensis Broth.

Fissidens hornschuchii Mont.

Fissidens lagenarius Mitt.*

Fissidens lindbergii Mitt.*

Fissidens palmatus Hedw.

Fissidens submarginatus Bruch

Fissidens zollingeri Mont.

Pottiaceae

Hyophiladelphus agrarius (Hedw.) R.H. Zander

Plaubelia sprengelii (Schwägr.) R.H. Zander

Splachnobryaceae

Splachnobryum obtusum (Brid.) Müll. Hal.

Stereophyllaceae

Entodontopsis leucostega (Brid.) Buck \& Ireland

* Espécies com nova citação para Ilha de Fernando de Noronha. 


\section{Chave artificial para espécies de Anthocerotophyta}

1. Esporos marrons a pretos, presença de pseudoelatérios.

Notothylas breutelii

1. Esporos amarelados, ausência de pseudoelatérios.

Notothylas orbicularis

\section{Notothyladaceae}

Notothylas breutelii (Gottsche) Gottsche, Bot. Zeitung (Berlin) 16(15): 21.1858.

Fig. 2.

Gametófito taloso, de cor verde escura, formando rosetas prostradas ao substrato. Cápsula abrindo por duas válvas; columela desenvolvida; esporos de cor marrom a preto; pseudoelatérios pequenos e globosos.

Material examinado: BRASIL. PE: Fernando de Noronha, Morro do Pico, 31/VII/1978, em rochas cobertas com uma fina camada de solo, sob uma vegetação baixa, D.M. Vital 8321 (SP133192); Forte dos Remédios, 03/VIII/1978, solo úmido, à sombra, D.M. Vital 8341 (SP133199); Morro de Farol, 03/VIII/1978, solo úmido na mata secundária, D.M. Vital 8335 (SP133197).

Distribuição geográfica: América tropical. No Brasil: BA, ES, MA, MS, PE, SP e Ilha de Fernando de Noronha.

Comentários: Notothylas breutelii foi identificada como N. vitali por Vital et al. (1991), que tem como características esporos amarelados e presença de elatérios. No entanto, os exemplares existentes no herbário SP e identificados como tal, demonstram esporos de cor marrom a pretos e pseudoelatérios, que são características de $N$. breutelii. Espécie encontrada em solos de áreas abertas, pouco sombreadas e úmidas. Amostras freqüentemente encontradas associadas à Fissidens bryoides e F. lindbergii. Nas expedições de 2013 e 2014 foram coletadas várias amostras de Notothylas sp., porém sem estruturas de reprodução, o que impossibilitou a confirmação da espécie. 

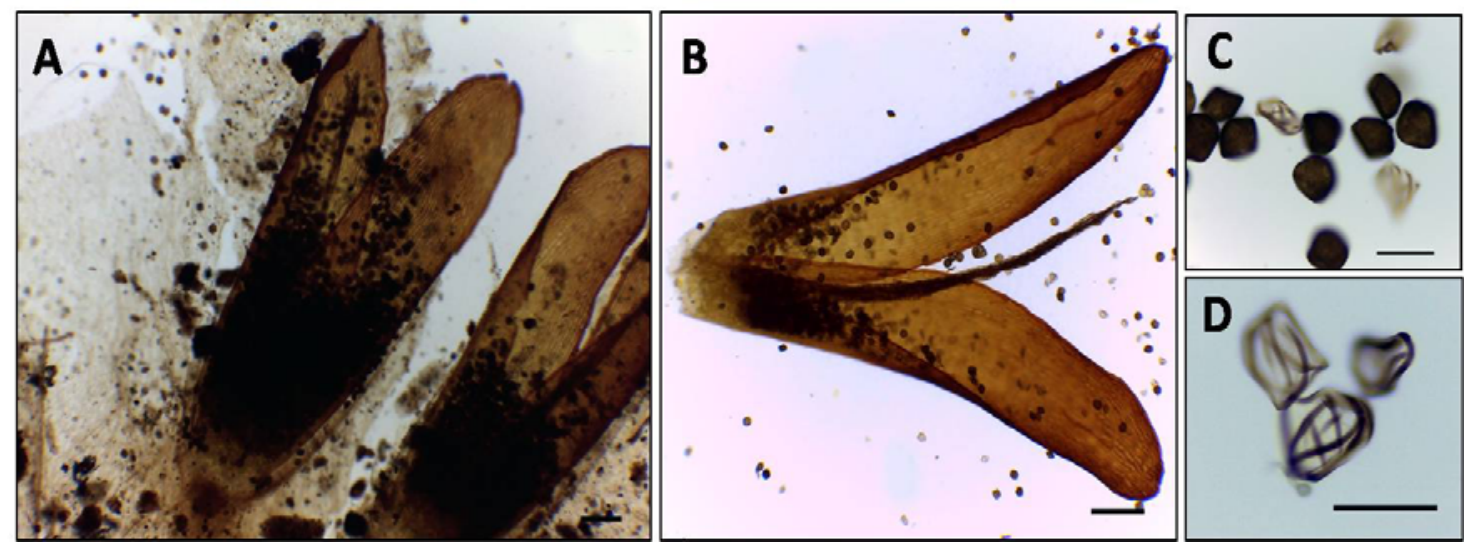

Figura 2: Notothylas breutelii (Gottsche) Gottsche, A- Visão geral do gametófito com dois esporófitos; B- Cápsula abrindo por duas válvas e com columela no centro; C- Esporos e DPseudo-elatérios globosos (D.M. Vital 8341). Escalas: A e B = 200 $\mu \mathrm{m}$; C e D = 50 $\mu \mathrm{m}$.

Notothylas orbicularis (Schwein.) Sull., Amer. J. Sci. Arts, 51: 75. 1846.

Fig. 3.

Gametófito taloso, de cor verde escura, formando rosetas prostradas ao substrato. Cápsula abrindo por um opérculo; ausência de columela; esporos de cor amarelada; ausência de pseudoelatérios.

Material examinado: BRASIL. PE: Fernando de Noronha, Alto Dois Abraços, 31/VII/1978, em solo úmido ao longo da estrada, D.M. Vital 8326 (SP133194).

Distribuição geográfica: América do Norte, Europa, Japão e África. No Brasil: AM, CE, PE e Ilha de Fernando de Noronha.

Comentários: Nova citação para Fernando de Noronha. As plantas analisadas foram encontradas, em solos úmidos, associadas à Fissidens bryoides e F. lindbergii. Os esporófitos de Notothylas orbicularis apresentam tamanhos menores que $N$. breutelii. 

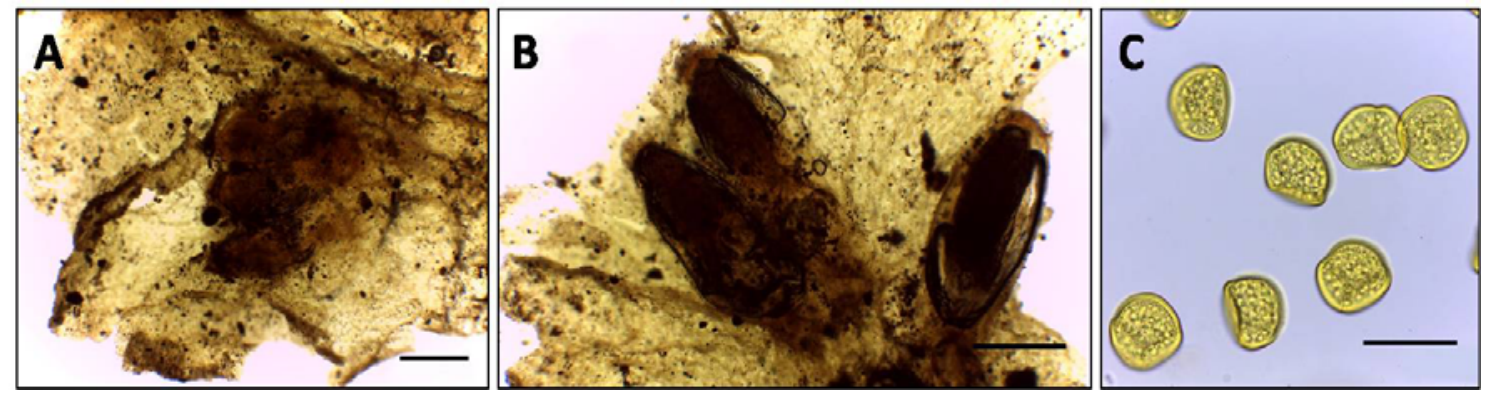

Figura 3: Notothylas orbicularis (Schwein.) Sull., A e B- Visão geral do gametófito com esporófitos e C- Esporos. (D.M. Vital 8326) Escalas: A e B = 500 $\mu \mathrm{m}$; C e D = 50 $\mu \mathrm{m}$.

\section{Chave artificial para espécies de Marchantiophyta}

1. Gametófito taloso Riccia ridleyi

1. Gametófito folhoso 2

2. Gametófito verde escuro a marrom avermelhado; lóbulo sacado; trigônios presentes Frullania ericoides

2. Gametófito verde claro a amarelado; lóbulo não sacado, trigônios ausentes.

Lejeunea laetevirens

\section{Frullaniaceae}

Frullania ericoides (Nees) Mont., Ann. Sci. Nat., Bot., sér. 2, 12: 51.1839.

Gametófito folhoso, cor verde escuro a vermelho-amarronzado, com ramificações irregulares; anfigastro bífido; células do filídio arredondadas a alongadas, com paredes formando trigônios; lóbulo sacado com abertura voltada para a base do caulídio. Esporófito não visualizado. Segundo Gradstein \& Costa (2003) apresenta perianto curto, cápsula globosa, perianto quilhado e verrucoso.

Material examinado: BRASIL. PE: Fernando de Noronha, Morro do Pico, 31/VII/1978, rochas nuas, quase no topo do morro, D.M. Vital 8313 (SP133187); Alto Dois Abraços, 02/VIII/1978, tronco vivo, na mata secundária, próximo ao morro, D.M. Vital 8334 (SP133196); Capim Açu (Sapata), 04/XI/2013, tronco vivo, 159 m alt., 
Pereira et al.136 (UB169841); Morro do Francês, 06/XI/2013, rocha ao longo da estrada, 195 m alt., Pereira et al.193 (UB169899).

Distribuição geográfica: África, Austrália, América do Norte, América do Sul, Ásia. No Brasil: AC, AL, AM, BA, CE, DF, ES, GO, MA, MG, MS, MT, PA, PB, PE, RJ, RR, RS, SC, SE, SP e Ilha de Fernando de Noronha.

Comentários: Frullania ericoides foi encontrada tanto no período seco quanto no chuvoso. Planta facilmente distinguível de Lejeunea laetevirens, por sua tonalidade mais escura, principalmente nos indivíduos mais antigos. Os filídios esquarosos também são outra característica bastante comum nesta espécie. Os lóbulos podem aparecer mais abertos, não sacados.

\section{Lejeuneaceae}

Lejeunea laetevirens Nees \& Mont., Hist. Phys. Cuba, Bot., Pl. Cell, 469. 1842.

Gametófito folhoso, de cor verde clara a amarelada. Caulídio de coloração na mesma tonalidade que os filídios e mede de 3-4 células de largura; anfigastro bífido, merófito formado por duas células. Células do filídio isodiamétricas, trigônios ausentes, ápice cuculado a obtuso; lóbulos não sacados de aparência inflada. Esporófito não visualizado. Segundo Gradstein \& Costa (2003) apresenta perianto quilhado.

Material examinado: BRASIL. PE: Fernando de Noronha, Morro do Pico, 31/VII/1978, grandes rochas na base do morro, D.M. Vital 8311 (SP133186); Alto dois Abraços, 02/VIII/1978, tronco vivo, na mata secundária, D.M. Vital 8333 (SP133195); Morro da Madeira, 17/XI/1989, rocha exposta, de frente para ilha Cabeluda, D.P. Costa \& O. Yano 1024 (SP228595); Morro do Piquinho, 01/XI/2013, rocha, $147 \mathrm{~m}$ alt., Pereira et al. 52 (UB169760); Capim Açu (Sapata), 04/XI/2013, tronco vivo, $159 \mathrm{~m}$ alt., Pereira et al. 114 (UB169818).

Distribuição geográfica: América do Norte, América do Sul, Ásia. No Brasil: AC, AL, AM, AP, BA, CE, DF, ES, GO, MA, MG, MS, MT, PA, PB, PE, RJ, RN, RR, RS, SC, SE, SP e Ilha de Fernando de Noronha. 
Comentários: Hepática bem distribuída na mata do Capim Açu (Ponta da Sapata) e no Morro do Piquinho. Espécie xero-tolerante (Gradstein \& Costa 2003), pode ser encontrada tanto na época seca quanto na chuvosa, cobrindo grandes paredões de rochas, de hábito freqüentemente epífito, hospedada em troncos vivos e rochas. Algumas amostras foram encontradas associadas à Calymperes palisotii e Frullania ericoides. Os lóbulos apresentam 1-2 dentes (uma célula de cada lado) e papila hialina, algumas vezes ausente. Na ilha, foram encontradas apenas duas hepáticas folhosas. Lejeunea laetevirens pode ser facilmente distinguida de F. ericoides, por sua cor verde claro e por apresentar lóbulos não sacados.

\section{Ricciaceae}

Riccia ridleyi A. Gepp, J. Linn. Soc., Bot., 27: 74. 1890.

Fig. 4.

Hepática talosa, talo sulcado na região mediana e às vezes bifurcado. Células diferenciadas (escamas) de cor violeta na margem dos talos. Esporófitos não visualizados. Segundo Gradstein \& Costa (2003) apresenta esporófito embutido no talo, cápsula globosa, sem pé e nem seta.

Material examinado: BRASIL. PE: Fernando de Noronha, Morro do Pico, 31/VII/1978, rochas no topo do morro, D.M. Vital 8314 (SP133188); Alto da Bandeira, 04/VIII/1978, solo, na mata rala, já na descida do morro, D.M. Vital 8347 (SP133200); Praia do Americano, 04/V/2014, solo ao longo da trilha, $32 \mathrm{~m}$ alt., Pereira et al. 219 (UB174407); Idem, 04/V/2014, solo entre rochas, na formação rochosa de frente para a praia, 52 m alt., Pereira et al. 241 (UB174429); Trilha grande do Atalaia, 08/V/2014, solo entre rochas, $62 \mathrm{~m}$ alt., Pereira et al. 380 (UB174568); Primeiro Mirante da Sapata, 09/V/2014, solo, 32 m alt., Pereira et al. 451 (UB174639); Base do Morro do Abreu, 09/V/2014, solo, 38 m alt., Pereira et al. 464 (UB174653); Segundo Mirante para Baia do Golfinhos, 10/V/2014, solo, 64 m alt., Pereira et al. 481 (UB174569); Mirante para Praia do Sancho, 10/V/2014, solo entre rochas, $61 \mathrm{~m}$ alt., Pereira et al. 497 (UB174677). 
Distribuição geográfica: América do Sul (Venezuela e Peru). No Brasil: Ilha de Fernando de Noronha.

Comentários: Riccia ridleyi é considerada uma espécie rara para o Brasil, com ocorrência apenas para Fernando de Noronha, Venezuela e Peru. Está na lista de flora brasileira ameaçada de extinção na categoria CR (Criticamente em Perigo), critérios B2ab (i, ii, iii) (CNCflora). Durante a segunda expedição, na estação chuvosa, essa espécie foi encontrada formando populações em vários pontos da ilha.
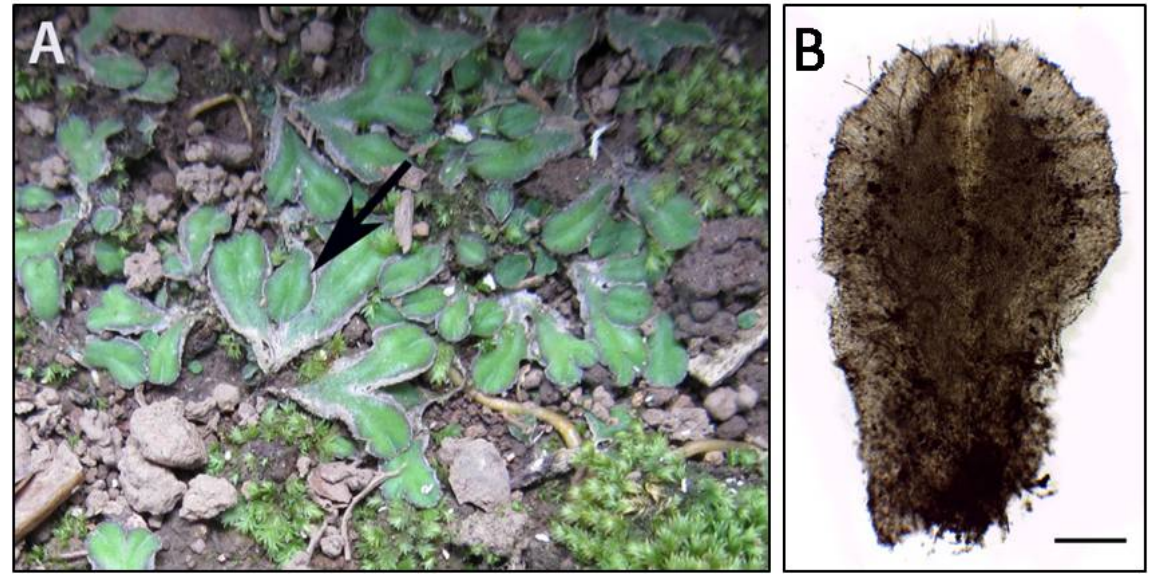

Figura 4: Riccia ridleyi A. Gepp. A- Margem do talo com bordas de cor violeta (seta) e B- Talo (Pereira et al. 241). Escala: B =500 $\mu \mathrm{m}$.

\section{Chave artificial para espécies de Bryophyta}

1.Plantas pleurocárpicas Entodontopsis leucostega

1.Plantas acrocárpicas

2.Filídios em disposição dística, presença de lâmina vaginante.

2.Filídios em disposição radial, ausência de lâmina vaginante. .14

3.Limbídio apenas na lâmina vaginante. .4

3. Limbídio em todo o filídio.

4.Limbídio apenas na lâmina vaginante de todos os filídios. .Fissidens submarginatus 
4.Limbídio apenas na lâmina vaginante da maioria dos filídios .5

5.Células da lâmina do filídio quadráticas a pentagonais, célula apical hialina presente.

Fissidens hornschuchii

5.Células da lâmina do filídio arredondadas e irregulares, célula apical hialina ausente.

Fissidens lagenarius

6.Células da lâmina do filídio lisas. 7

6.Células da lâmina do filídio unipapilosas. .12

7.Gametófitos flabelados, mais largos do que longos . .8

7.Gametófitos não flabelados, mais longos do que largos .10

8.Células da lâmina do filídio curto-retangulares a arredondadas, nódulos axilares presentes no caulídio

Fissidens zollingeri

8.Células da lâmina do filídio romboidais a retangulares ou irregulares, nódulos axilares ausentes.

9.Células da lâmina do filídio com paredes sinuosas, células da região mediana não diferenciadas e dispostas em fileiras paralelas com relação à costa....Fissidens flaccidus

9.Células da lâmina do filídio com paredes não sinuosas, células da região mediana diferenciadas e dispostas em diagonal com relação à costa......

Fissidens palmatus

10.Limbídio biestratoso, filídios linear-lanceolados a oblongolanceolados. Fissidens curvatus

10.Limbídio uniestratoso, filídios oblongos a oblongo-ovalados. .11

11.Nódulos axilares hialinos presentes, células dos filídios organizadas em fileiras distintas.

.Fissidens crispus

11.Nódulos axilares hialinos ausentes, células dos filídios não organizadas em fileiras distintas

Fissidens bryoides 
12. Células do filídio hexagonais a romboidais, com paredes sinuosas, costa subpercurrente (finalizando 11-18 células abaixo do ápice) Fissidens lindbergii

12.Células do filídio curto-hexagonais, quadráticas ou arredondadas, sem paredes sinuosas, costa percurrente ou curto-excurrente. .13

13.Células justacostais longo retangulares na base da lâmina vaginante. Fissidens angustifolius 13.Células justacostais curto retangulares a quadráticas na base da lâmina vaginante Fissidens goyazensis 14.Costa larga, com 6-10 células de largura, células da região basal hialinas....15 14.Costa estreita, com 2-6 células de largura, células da região basal não hialinas .17

15.Base dos filídios com células hialinas distinguindo-se de forma abrupta das células clorofiladas, presença de teníolas

Calymperes palisotii

15.Base dos filídios com células hialinas distinguindo-se de forma gradual das células clorofiladas ou não diferenciadas, ausência de teníolas 16

16.Costa coberta por células retangulares na superfície ventral, ausência de células mamilosas no ápice do filídio Hyophiladelphus agrarius

16.Costa coberta por células quadradas a arredondadas na superfície ventral, presença de células mamilosas no ápice do filídio Plaubelia sprengelii

17.Filídios com margem distinta, células da borda da região mediana superior diferenciadas a pouco diferenciadas. .18

17.Filídios sem margem distinta, células da borda do ápice pouco diferenciadas..........21

18.Ápice dos filídios apiculado e células da base arredondadas Gemmabryum apiculatum

18.Ápice dos filídios acuminados e células da base quadráticas a curto retangulares 
19.Margem dos filídios inteira na porção mediana superior.

Bryum atenense

19.Margem dos filídios levemente denteada na porção mediana superior. .20

20.Caulídios levemente avermelhados na base, costa estreita, com 2-4 células de largura, filídios agrupados no ápice do caulídio.

Bryum coronatum

20.Caulídios esverdeados, costa forte, com 4-6 células de largura, filídios não agrupados no ápice do caulídio

Gemmabryum subapiculatum

21.Filídios oblongos a ligulados, com margem lisa a levemente crenulada no ápice

Splachnobryum obtusum

21.Filídios lanceolados, estreitamente ovalado-lanceolados a linear-lanceolados, com margem serrulada na região mediana superior

22

22.Filídios estreitamente ovalado-lanceolados, células da região mediana superior do filídio mamilosas

Philonotis cernua

22.Filídios estreitamente lanceolados a linear-lanceolados, células da região mediana superior do filídio proradas

Dicranella varia

\section{Bartramiaceae}

Philonotis cernua (Wilson) D.G. Griffin \& W.R. Buck, Bryologist 92(3): 376. 1989. Fig. 5.

Gametófitos verde-amarelados; filídios em disposição radial, lanceolados a estreitamente ovalado-lanceolados; ápice acuminado; costa estreita, com 2-6 células de largura, percurrente. Células da margem do filídio serrulada a partir da região mediana superior. Células da lâmina do filídio retangulares e mamilosas a partir da região mediana superior e células da região basal lisas. Esporófito não visualizado. Segundo Sharp et al. (1994), a espécie apresenta esporófito inclinado a reto, com cápsula globosa e peristômio ausente.

Material examinado: BRASIL. PE: Fernando de Noronha, Vila dos Remédios, 05/V/2013, solo entre rochas, próximo à Igreja dos Remédios, 49 m alt., Pereira et al. 
273 (UB174461); Morro da Madeira, 17/XI/1989, rocha, D.P. Costa\& O. Yano 1034 (SP228605).

Distribuição geográfica: África, América do Norte, América do Sul, Ásia. No Brasil: CE, DF, GO, MA, MG, MT, PB, PR, RJ, RS, SC, SE, SP e Ilha de Fernando de Noronha.

Comentários: Nova citação para Fernando de Noronha, porém rara neste local, pois foi encontrada apenas na Vila dos Remédios e em pouca quantidade.
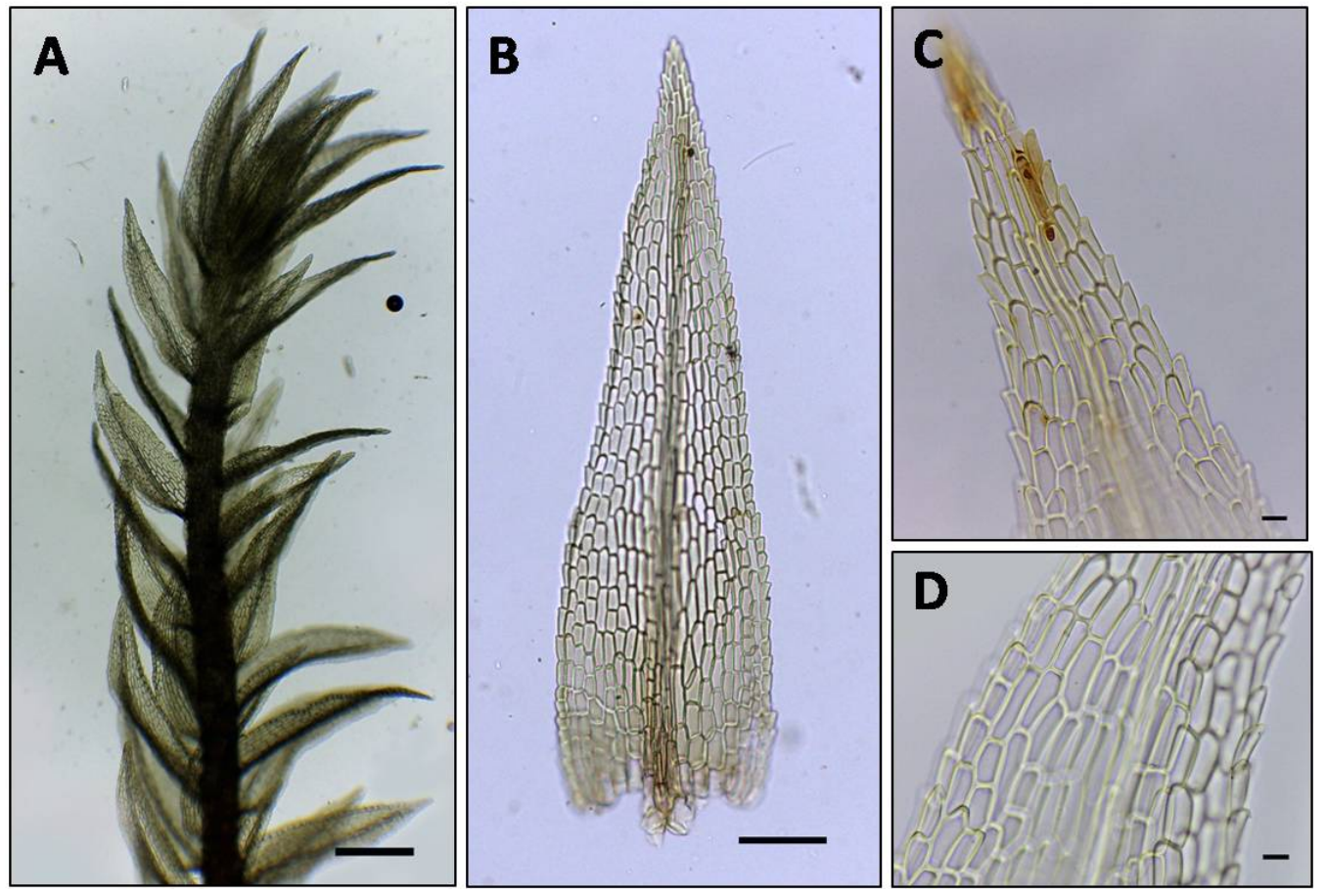

Figura 5: Philonotis cernua (Wilson) D.G. Griffin \& W.R. Buck, A- Visão geral do gametófito; B- Filídio; C- Ápice do filídio; D- Células da lamina do filídio (Pereira et al. 273). Escalas: $\mathrm{A}=200 \mu \mathrm{m} ; \mathrm{B}=100 \mu \mathrm{m} ; \mathrm{C}$ e $\mathrm{D}=10 \mu \mathrm{m}$.

\section{Bryaceae}

Bryum atenense R.S. Williams, Bull. New York Bot. Gard. 6(21): 231. 1909.

Fig. 6 B-C.

Gametófitos verde-claros, caulídios curtos. Filídios em disposição radial, oblongos a oblongo-lanceolados; ápice acuminado formando aristas; costa estreita, com 2-6 células de largura, longo-excurrente. Células da borda diferenciadas, formando 
margem com uma célula de largura, inteira na porção mediana superior. Células da lâmina do filídio lisas, células da região mediana hexagonais e células da região basal quadráticas a curto-retangulares. Esporófito não visualizado. Segundo Sharp et al. (1994), o gênero apresenta esporófito terminal, com cápsula piriforme e peristômio duplo.

Material examinado: BRASIL. PE: Fernando de Noronha, Estrada velha do Sueste, indo para o Morro do Abreu, 09/V/2014, em solo, 43 m alt., Pereira et al. 453 (UB174642).

Distribuição geográfica: América do Sul (Bolívia). No Brasil: GO, MT, MS e Ilha de Fernando de Noronha.

Comentários: Nova citação para Fernando de Noronha, rara neste local, pois foi encontrada apenas nas proximidades do Morro do Abreu. Apresenta similaridade morfológica com Gemmabryum subapiculatum. Bryum atenense distingue-se principalmente por apresentar gametófito muito pequeno e delicado, além de apresentar filídios mais curtos e com células quadráticas a curto-retangulares na base dos filídios.

Bryum coronatum Schwägr., Spec. Musc. Frond., Suppl. 1(2): 103-104, pl. 71. 1816.

Gametófitos verde-amarronzados, caulídios avermelhados na base. Filídios em disposição radial, agrupados no ápice do caulídio, oblongo-lanceolados a ovalados; ápice agudo; costa estreita, com 2-4 células de largura, excurrente. Células da borda diferenciadas, alongadas, formando margem com 1-2 células de largura, levemente denteada na porção mediana superior. Células da lâmina do filídio lisas, células da região mediana hexagonais a longo-hexagonais e células da região basal retangulares. Esporófito não visualizado. Segundo Sharp et al. (1994), a espécie apresenta esporófito terminal, longo com cápsula pêndula e peristômio duplo.

Material examinado: BRASIL. PE: Fernando de Noronha, Morro do Piquinho, 01/XI/2013, solo, na base do morro, $147 \mathrm{~m}$ alt., Pereira et al. 63 (UB169770); Praça Flamboyant, 05/V/2014, solo, 93 m alt., Pereira et al. 250 (UB174438); Vila dos Remédios, 05/V/2014, cimento, nas ruínas do antigo presídio, ao lado do palácio São 
Miguel, 75 m alt., Pereira et al. 254 (UB174442); Cemitério, 07/V/2014, cimento entre da mureta, 98 m alt., Pereira et al. 339 (UB174528).

Distribuição geográfica: África, América Central, América do Norte, América do Sul, Ásia, Oceania. No Brasil: AC, AM, BA, CE, DF, GO, MA, MG, MS, MT, PA, PB, PI, PE, PR, RJ, RO, RR, RS, SC, SP e Ilha de Fernando de Noronha.

Comentários: Espécie encontrada em associação com Gemmabryum apiculatum, G. subapiculatum e Splachnobryum obtusum. Planta bastante similar a Bryum atenense por apresentar caulídios levemente avermelhados, principalmente nos exemplares coletados na estação seca e a Gemmabryum subapiculatum pelo comprimento e disposição dos filídios no gametófito. B. atenense difere de $B$. coronatum principalmente por apresentar o ápice do filídio acuminado e difere de $G$. subapiculatum por apresentar células da região basal mais cumpridas, ou seja, longoretangulares.

Gemmabryum apiculatum (Schwägr.) J.R. Spence \& H.P. Ramsay. Phytologia 87(2): 65. 2005.

Fig. 6 A.

Gametófitos verde-amarelados a avermelhados. Filídios em disposição radial, oblongos a oblongo-lanceolados, côncavos; ápice apiculado; costa estreita, com 2-6 células de largura, percurrente. Células da borda pouco diferenciadas, margem inteira em todo o filídio. Células da lâmina do filídio lisas, células da região mediana oblongoromboidais e da região basal arredondadas a quadráticas. Esporófito não visualizado. Segundo Sharp et al. (1994), a espécie apresenta esporófito delgado, com cápsula horizontal e oblongo-piriforme e peristômio duplo.

Material examinado: BRASIL. PE: Fernando de Noronha, Alojamento do ICMBio, 03/XI/2013, solo, 55 m alt., Pereira et al. 106 (UB169811); Sitio Leão (antigo viveiro de Mudas do projeto Tamar), 05/XI/2013, solo, $51 \mathrm{~m}$ alt., Pereira et al. 161-A (UB169867); Morro do Piquinho, 06/V/2014, solo entre rochas, na base do morro, 164 m alt., Pereira et al. 297 (UB174486); Praia do Leão, 07/V/2014, solo entre rochas, de 
frente para a praia, 25 m alt., Pereira et al. 340(UB174529); ICMBio, 08/V/2014, solo, 55 m alt., Pereira et al. 353 (UB174541).

Distribuição geográfica: América do Sul e Austrália. No Brasil: AC, AM, BA, CE, DF, MA, MG, PA, PI, PB, PR, RJ, RN, RS, SC, SP e Ilha de Fernando de Noronha.

Comentários: Nova citação para Fernando de Noronha, porém, segundo Sharp et al. (1994), essa espécie é facilmente confundida com outras espécies de Bryum e Pohlia por apresentar variações morfológicas como tamanho e cor, além de ápice acuminado e concavidade nos filídios. Mas uma das principais características que facilita a identificação é o fato dos caulídios serem avermelhados e os filídios amarelados.

Gemmabryum subapiculatum (Hampe) J.R. Spence \& H.P. Ramsay, Phytologia 87(2): 68. 2005.

Fig. 6 D.

Gametófitos verde-claros a verde-escuros, caulídios esverdeados, alongados. Filídios em disposição radial, oblongo-lanceolados; ápice agudo a levemente acuminado; costa forte, com 4-6 células de largura; longo-excurrente. Células da borda diferenciadas, alongadas, formando margem com 1-2 células de largura na região mediana do filídio e levemente denteada na porção mediana superior. Células da lâmina do filídio lisas, células da região mediana longo-hexagonais e da região basal retangulares a longo-retangulares. Esporófito não visualizado. Segundo Sharp et al. (1994), a espécie apresenta esporófito terminal, delgado com cápsula pêndula e alongada e peristômio duplo.

Material examinado: BRASIL. PE: Fernando de Noronha, Vila dos Remédios, 31/X/2013, solo, nas ruínas do antigo presídio, ao lado do palácio São Miguel, 54 m alt., Pereira et al. 29 (UB169744); Cacimba do Padre, 04/XI/2013, cimento, 21 m alt., Pereira et al. 156 (UB169861); Cemitério, 05/XI/2013, cimento de túmulo, 115 m alt., Pereira et al. 178 (UB169884); Praça Flamboyant, 05/V/2014, solo, 93 m alt., Pereira et al. 250 (UB174438); Mirante da Praia do Sancho, 10/V/2014, solo, 61 m alt., Pereira et al. 496 (UB174676). 
Distribuição geográfica: América do Sul, América do Norte e Austrália. No Brasil: AM, BA, DF, GO, MA, MT, PA, PR, RJ, RO, RR, RS, SP e Ilha de Fernando de Noronha.

Comentários: Nova citação para Fernando de Noronha, encontrada em muitos pontos de coleta e freqüentemente associada a outras espécies, como Fissidens lindbergii, Gemmabryum apiculatum, Plaubelia sprengelii e Splachnobryum obtusum. Em alguns pontos, essa planta foi encontrada com gametófitos bastante longos.
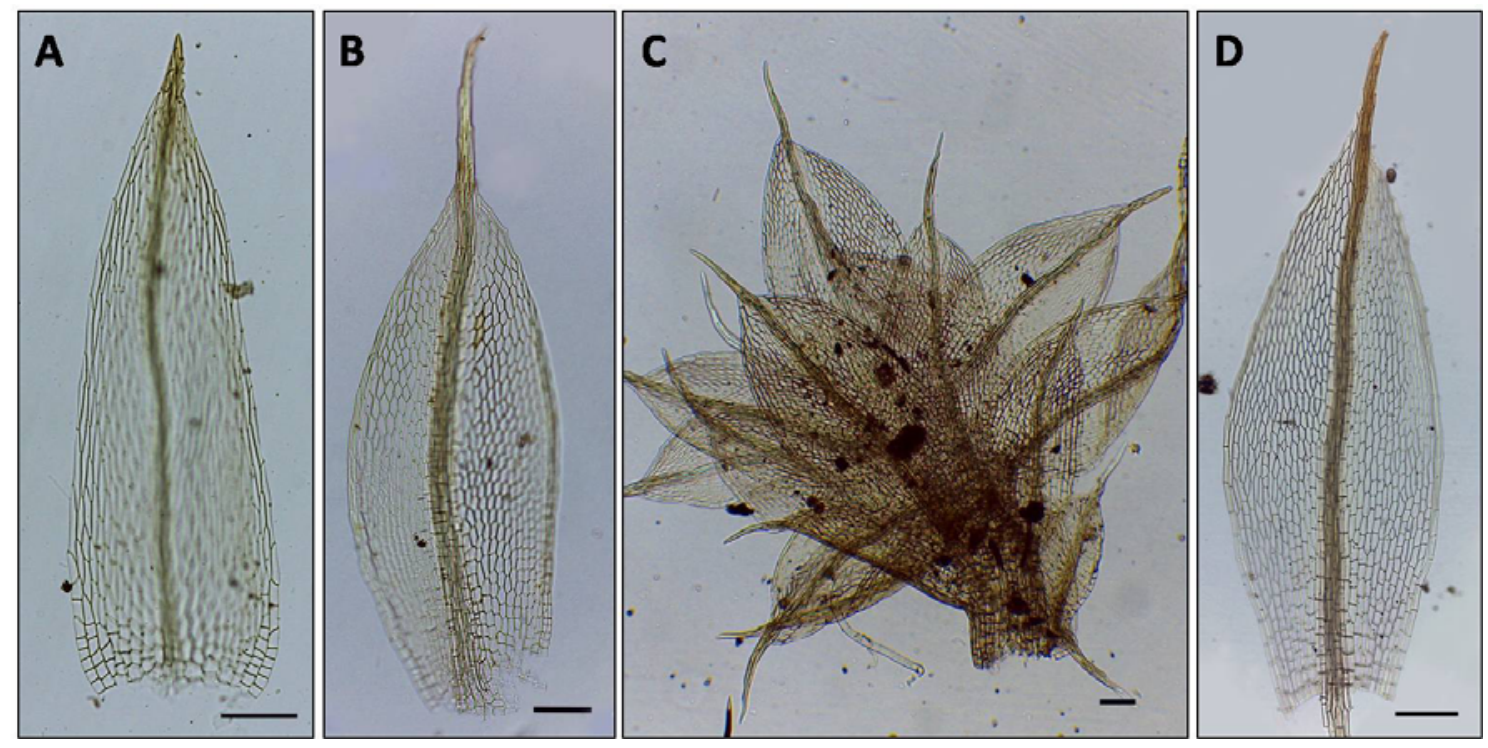

Figura 6: A- Filídio de Gemmabryum apiculatum (Schwägr.) J.R. Spence \& H.P. Ramsay. (Pereira et al. 106); (B-C)- Bryum atenense R.S. Williams, B- Filídio; C- Visão geral do gametófito (Pereira et al. 453); D- Filídio de Gemmabryum subapiculatum (Hampe) J.R. Spence \& H.P. Ramsay (Pereira et al. 29). Escalas: A-D = 100 $\mu$.

Planta coletada principalmente em cimento em áreas abertas e algumas vezes em solo de áreas sombreadas.

\section{Calymperaceae}

Calymperes palisotii Schwägr., Sp. Musc. Frond., Suppl. 1(2): 334. pl. 98. 1816.

Gametófitos verde-amarelados a verde-escuros, espiralados quando secos. Filídios em disposição radial, oblongo a lanceolados; dimórficos, com o ápice em 
alguns dos filídios apresentando propágulos (gemas); costa larga, com 6-10 células de largura, percurrente. Células da margem (intramarginais) formando teníolas conspícuas; células da lâmina do filídio lisas e isodiamétricas; região basal do filídio formada em sua maioria por células cancelinas mais largas, hialinas e lisas, que se distinguem abruptamente das células clorofiladas. Esporófito não visualizado. Segundo Reese (1993), a espécie apresenta esporófito com seta longa, cápsula exserta e peristômio ausente.

Material examinado: BRASIL. PE: Fernando de Noronha, Vila dos Remédios, 31/X/2013, tronco vivo, ao lado do palácio São Miguel, 54 m alt., Pereira et al. 14 (UB169731); Morro do Piquinho, 01/XI/2013, rocha, na base do morro, próximo à fenda, 147 m alt., Pereira et al. 69 (UB169776); Morro do Pico, 31/VII/1978, rocha, na base do morro, D.M. Vital 8312 (SP147363); Planície da Viração, 02/VIII/1978, rocha, próximo à mata, D.M. Vital 8337 (SP147376); Baia dos Golfinhos, 03/XI/2013, tronco vivo, na trilha para a Baia, 65 m alt., Pereira et al. 92 (UB169797); Mirante para a Praia do Sancho, 03/XI/2013, rocha, na trilha depois do mirante dos golfinhos, $64 \mathrm{~m}$ alt., Pereira et al. 102 (UB169807); Cacimba do Padre, 04/XI/2013, tronco vivo, $21 \mathrm{~m}$ alt., Pereira et al. 154 (UB169859); Morro do Francês, 06/XI/2013, rocha, na margem da estrada, 195 m alt., Pereira et al. 196 (UB169900); Estrada para a Praia do Bode, 04/V/2014, rocha, próximo à mata, 45 m alt., Pereira et al. 204 (UB174397); Praça Flamboyant, 05/V/2014, tronco morto, 93 m alt., Pereira et al. 246 (UB174434); Trilha para a Vila da Vacaria, 06/V/2014, rocha, 77 m alt., Pereira et al. 307 (UB17496); Morro da Madeira, 08/V/2014, tronco vivo, 74 m alt., Pereira et al. 373 (UB174561); Vila Quixaba, 09/V/2014, tronco vivo, 93 m alt., Pereira et al. 386 (UB174574); Capim Açu (Sapata), 09/V/2014, tronco morto, $139 \mathrm{~m}$ alt., Pereira et al. 430 (UB174618); Farol da Sapata, 09/V/2014, tronco vivo, 185m alt., Pereira et al. 437 (UB174625); Ponta da Sapata, 20/XI/1989, tronco vivo, D.P. Costa \& O. Yano 1051 (SP228622).

Distribuição no Brasil: AL, AM, AP, BA, ES, GO, MA, MG, MS, MT, PA, PB, PE, PI, PR, RJ, RN, RO, RR, SE, SP, TO e Ilha de Fernando de Noronha.

Comentários: Espécie amplamente distribuída na ilha, encontrada em vários pontos e freqüentemente sobre o tronco de árvores vivas ou mortas, raízes e também sobre rochas, com gametófitos dispersos sobre o substrato ou formando tufos densos. Encontrada associada à Lejeunea laetevirens e Frullania ericoides. 


\section{Dicranaceae}

Dicranella varia (Hedw.) Schimp., Coroll. Bryol. Eur. 13. 1856.

Fig. 7.

Gametófitos verde-claros a verde-amarelados, levemente falcados quando secos. Filídios em disposição radial, estreitamente lanceolados a linear-lanceolados; ápice agudo; costa estreita, com 2-6 células de largura, percurrente. Células da margem levemente denticulada na região mediana superior; células da lamina longo-retangulares e células da base oblongo-linear, células da região mediana superior do filídio proradas e da região basal lisas. Esporófito não visualizado. Segundo Sharp et al. (1994), a espécie apresenta esporófito alongado com cápsula levemente curvada e ovóide e peristômio simples.

Distribuição geográfica: África, América Central, América do Norte, América do Sul, Ásia, Europa. No Brasil: CE, ES, GO, MT, SP e Ilha de Fernando de Noronha.
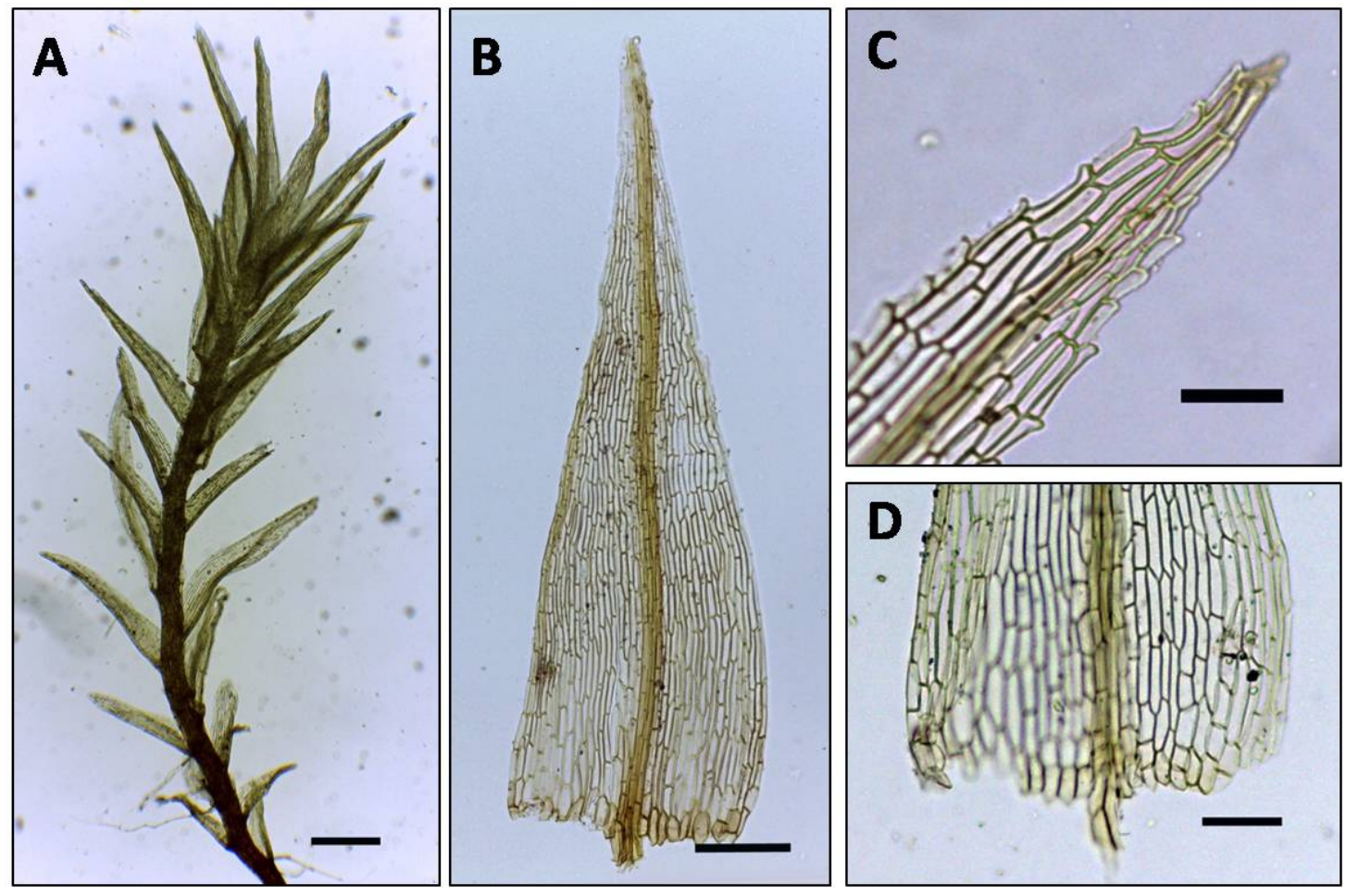

Figura 7: Dicranella varia (Hedw.) Schimp., A- Visão geral do gametófito; B- Filídio; CÁpice agudo do filídio mostrando margem levemente denticulada; D- Base do filídio (Pereira et al. 292). Escalas: $\mathrm{A}=200 \mu \mathrm{m} ; \mathrm{B}=100 \mu \mathrm{m}$ e $\mathrm{D}=50 \mu \mathrm{m}$. 
Material examinado: BRASIL. PE: Fernando de Noronha, Morro do Piquinho, 06/V/2013, solo entre rochas, na base do morro, próximo à caverna, $164 \mathrm{~m}$ alt., Pereira et al. 292 (UB174481).

Comentários: Espécie com nova citação para Fernando de Noronha, cosiderada rara, pois foi encontrada apenas nas proximidades do Morro do Piquinho. Planta com coleta registrada no mesmo local em 1978, 2013 e 2014. Apesar de Dicranella varia ainda ocorrer no mesmo local desde a primeira coleta, a área em que ela foi coletada, base do Morro do Piquinho, é muito pequena, cerca de 10 metros quadrados e é utilizado para atividades de ecoturismo.

\section{Fissidentaceae}

Fissidens angustifolius Sull., Proc. Amer. Acad. Arts. 5: 275. 1861.

Fig. 8.

Gametófitos flabelados, verde-amarelados; nódulos axilares hialinos presentes no caulídio. Filídios em disposição dística, lanceolados, limbídio confluente com o ápice ou finalizando algumas células abaixo; costa percurrente. Células da lâmina do filídio unipapilosas, irregulares, curto-hexagonais na região mediana superior, células justacostais longo-retangulares na base da lâmina vaginante. Esporófito não visualizado. Segundo Bordin \& Yano (2013), essa espécie apresenta esporófito terminal, cápsula cilíndrica e peristômio simples (do tipo scariosus).

Material examinado: BRASIL. PE: Fernando de Noronha, Vila dos Remédios, 31/VIII/1978, solo de barrancos próximo à estrada, D.M. Vital 8338 (SP147377); Praia do Americano, 04/V/2014, solo ao longo da trilha, formando um grande tapete, $32 \mathrm{~m}$ alt., Pereira et al. 218 (UB174406); Trilha para o Mirante dos Golfinhos, 04/V/2014, solo, próximo à estrada, no início da trilha , 52 m alt., Pereira et al. 236 (UB17424); Praia do Leão, 07/V/2014, solo entre rochas, de frente para o Morro do Leão, 25 m alt., Pereira et al. 340 (UB174529); Trilha grande do Atalaia, 08/V/2014, solo, $81 \mathrm{~m}$ alt., Pereira et al. 377 (UB174565); Capim Açu (Sapata), 09/V/2014, solo, no estacionamento do início da trilha, 176 m alt., Pereira et al. 407 (UB174595); Primeiro Mirante da Sapata, 09/V/2014, rocha, 32 m alt., Pereira et al. 448 (UB174636); Estrada 
velha do Sueste, indo para o Morro do Abreu, 09/V/2014, em solo, 43 m alt., Pereira et al. 453 (UB174642); Estrada velha do Sueste, indo para o Morro do Abreu, 09/V/2014, em solo, 43 m alt., Pereira et al. 460 (UB174649); Baia dos Golfinhos, 10/V/2014, em solo, 65 m alt., Pereira et al. 480 (UB174659); Mirante da Praia do Sancho, 10/V/2014, solo, $61 \mathrm{~m}$ alt., Pereira et al. 494 (UB174673).

Distribuição geográfica: África, América do Norte, América Central, América do Sul, Ásia. No Brasil: AC, AM, BA, CE, GO, MA, PA, PB, PE, PI, RJ, RO, RS, SP e Ilha de Fernando de Noronha.

Comentários: Nova citação para Fernando de Noronha, encontrada formando tapetes, é muito similar a Fissidens lindbergii por apresentar gametófito flabelado, limbídio em toda a lâmina e células unipapilosas, porém, F. lindbergii tem células hexagonais, costa finalizando abaixo do ápice e, às vezes, apresentando tons avermelhados.
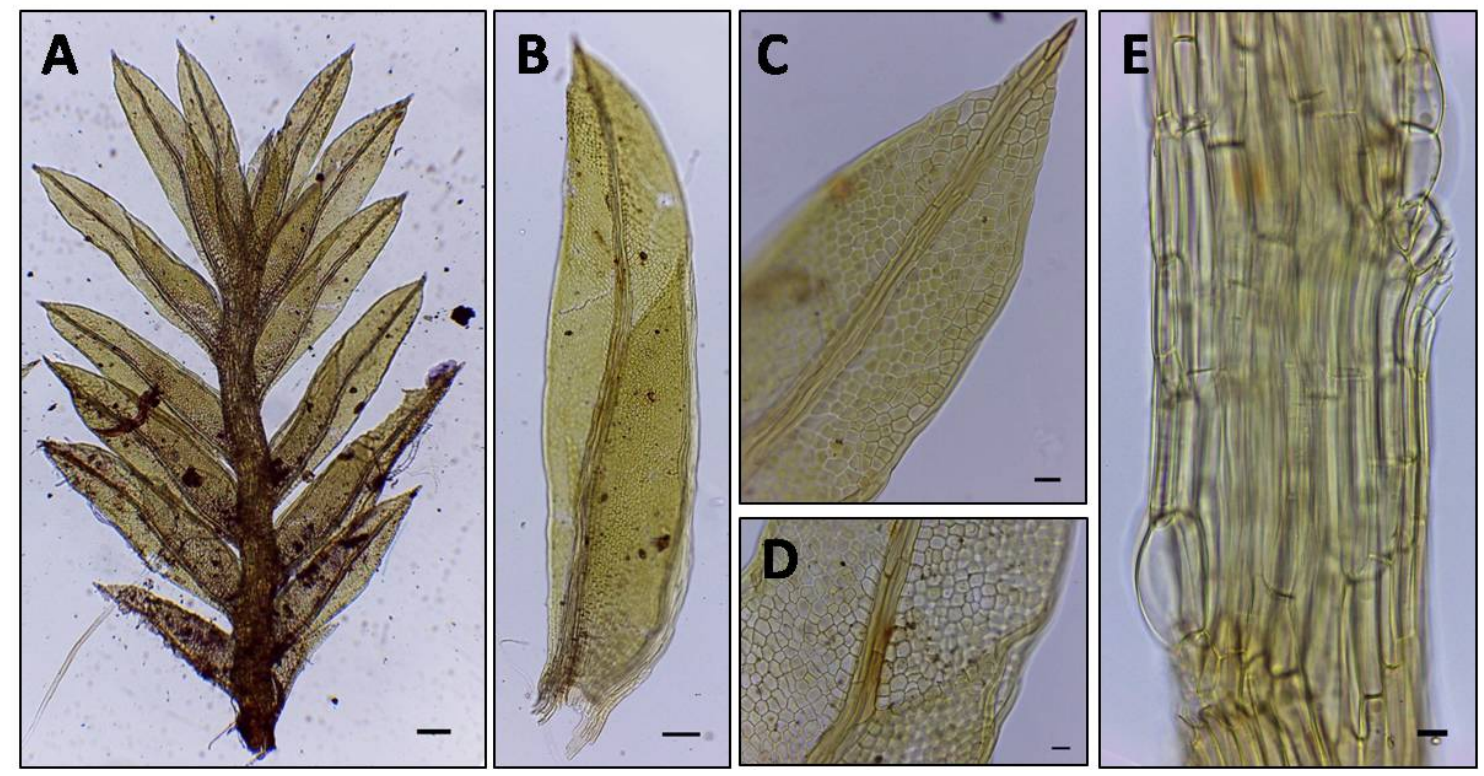

Figura 8: Fissidens angustifolius Sull., A- Visão geral do gametófito; B- Filídio; C- Ápice do filídio; D-; Células da região mediana do filídio; E- Caulídio mostrando nódulos axilares hialinos (Pereira et al. 222). Escalas: $\mathrm{A}=100 \mu \mathrm{m} ; \mathrm{B}=50 \mu \mathrm{m}$; C, D e E $=10 \mu \mathrm{m}$. 
Fissidens bryoides Hedw., Sp. Musc. Frond. 153. 1801.

Gametófitos não flabelados, verde-claros; nódulos axilares hialinos ausentes no caulídio. Filídios em disposição dística, oblongos a oblongo-ovalados, limbídio uniestratoso, finalizando 3-8 células abaixo do ápice e antes da base; costa percurrente. Células da lâmina do filídio lisas, curto-hexagonais, quadráticas a arredondadas, não organizadas em fileiras distintas. Esporófito não visualizado. Segundo Bordin \& Yano (2013), essa espécie apresenta esporófito terminal, cápsula cilíndrica e peristômio simples (do tipo bryoides).

Material examinado: BRASIL. PE: Fernando de Noronha, Trilha para Mirante dos Golfinhos, 04/V/2014, solo entre rochas, próximo à estrada, na mata fechada, no início da trilha, 52 m alt., Pereira et al. 235 (UB174423); Vila dos Remédios, 05/V/2014, cimento ao lado do palácio São Miguel, $75 \mathrm{~m}$ alt., Pereira et al. 258 (UB174446); Forte dos Remédios, 03/VIII/1978, solo de barrancos úmidos à sombra, D.M. Vital 8341 (SP133199); Trilha para Vila da Vacaria, 06/V/2014, solo, 82 m alt., Pereira et al. 304 (UB17493); Capim Açu (Sapata), 04/VIII/1978, solo à sombra parcial, próximo à praia, D.M. Vital 8348 (SP147385); Morro do Pico, 31/VII/1978, solo sob vegetação baixa e rala, próximo à base do Pico, D.M. Vital 8347 (SP133200).

Distribuição geográfica: África, América do Norte, América Central, América do Sul, Ásia, Europa, Oceania. No Brasil: PR, SP e Ilha de Fernando de Noronha.

Comentários: Planta encontrada associada à Riccia ridleyi e a Notothylas breutelii, muito similar a Fissidens crispus pelo formato do filídio e das células. Podem ser diferenciadas pela ausência de nódulos axilares hialinos em F. bryoides.

Fissidens crispus Mont., Ann. Sci. Nat., Bot., sér. 2, 9: 57. 1838.

Fig. 9.

Gametófitos não flabelados, verde-claros; nódulos axilares hialinos presentes no caulídio. Filídios em disposição dística, oblongos a oblongo-ovalados, com limbídio confluente ou finalizando 3-4 células abaixo do ápice; costa percurrente. Células da lâmina do filídio lisas, curto-hexagonais, quadráticas a arredondadas, organizadas em 
fileiras distintas. Esporófito não visualizado. Segundo Bordin \& Yano (2013), essa espécie apresenta esporófito terminal, cápsula globosa e peristômio simples (do tipo bryoides).

Material examinado: BRASIL. PE: Fernando de Noronha, Baia dos Golfinhos, 03/XI/2013, solo, na trilha para o mirante, 65 m alt., Pereira et al. 86 (UB169791); Praia do Sancho, 03/XI/2013, solo, próximo à trilha para praia, $64 \mathrm{~m}$ alt., Pereira et al. 95 (UB169800); Capim Açu (Sapata), 04/XI/2013, solo, na trilha, 159 m alt., Pereira et al.109 (UB169813); Estrada para a Praia do Bode, 04/V/2014, solo, próximo à mata, 45 m alt., Pereira e tal. 206 (UB174394); Praia do Americano, 04/V/2014, solo ao longo da trilha, 32 m alt., Pereira et al. 221 (UB174409); Estrada velha do Sueste, indo para o Morro do Abreu, 09/V/2014, em solo, 43 m alt., Pereira et al. 452 (UB174641); Baia dos Golfinhos, 10/V/2014, em solo, próximo ao segundo mirante, 65 m alt., Pereira et al. 489 (UB174668).

Distribuição geográfica: África, América do Norte, América Central, América do Sul, Europa. No Brasil: AM, BA, CE, DF, ES, GO, MG, MT, PE, PR, RJ, RO, RR, RS, SC, SP, TO e Ilha de Fernando de Noronha.
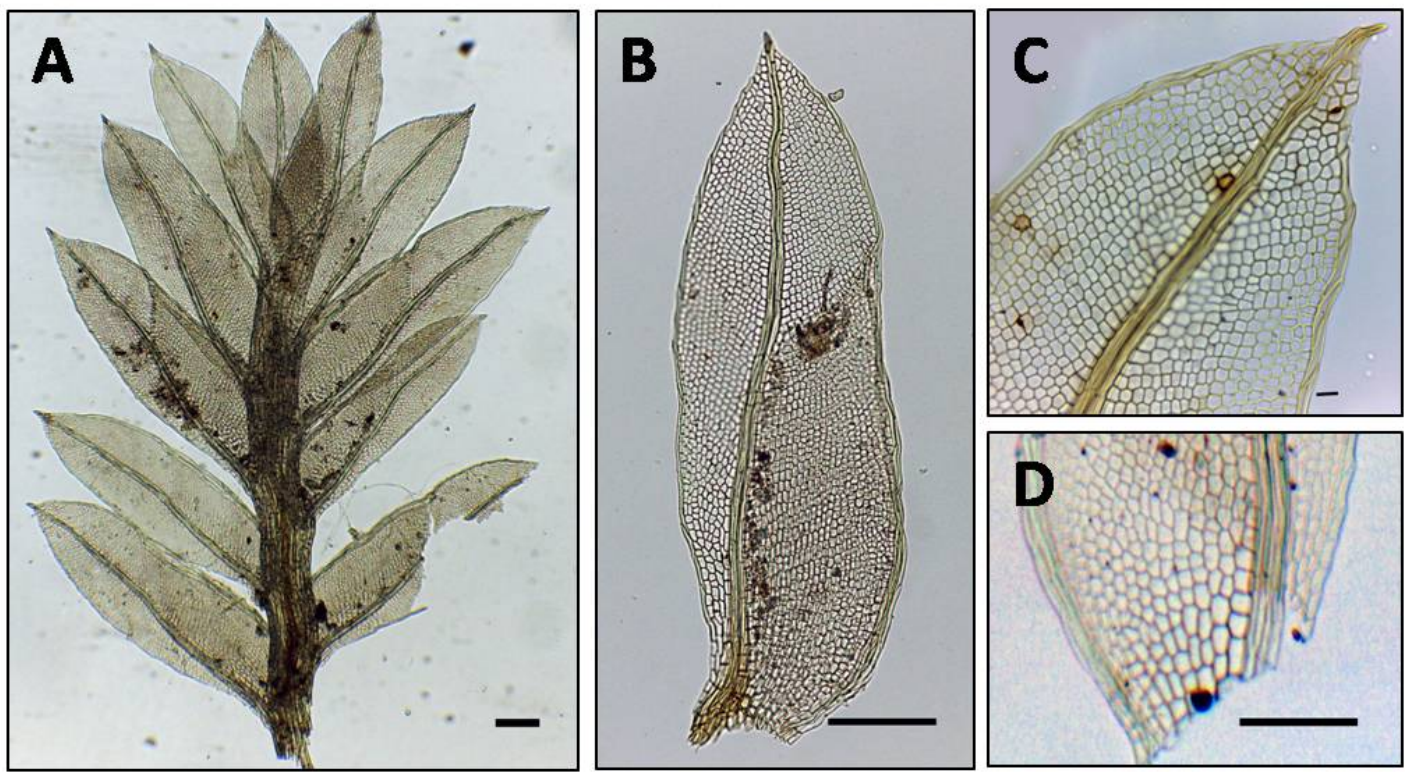

Figura 9: Fissidens crispus Mont., A- Visão geral do gametófito; B- Filídio; C- Ápice do filídio mostrando células organizadas em fileiras distintas; D- Base do filídio (Pereira et al. 86). Escalas: A, B e D $=100 \mu \mathrm{m} ; \mathrm{C}=10 \mu \mathrm{m}$. 
Comentários: Nova citação para Fernando de Noronha. Muito similar a Fissidens bryoides, diferindo por apresentar nódulos axilares no caulídio e por ter células menores na lâmina do filídio, seguindo uma organização vertical.

Fissidens curvatus Hornsch., Linnaea 15: 148. 1841. Fig. 10 A-B.

Gametófitos não flabelados, verde-claros a amarelados; nódulos axilares hialinos presentes no caulídio. Filídios em disposição dística, longos, linear-lanceolados a oblongo-lanceolados, quando secos tem forma curvada; limbídio em todo o filídio, confluente com a costa, biestratoso (1-2 células de largura); costa percurrente de cor amarelada. Células da lamina do filídio lisas e com formas irregulares. Esporófito não visualizado. Segundo Bordin \& Yano (2013), essa espécie apresenta esporófito terminal, cápsula ovóide e peristômio simples (do tipo bryoides).

Material examinado: BRASIL. PE: Fernando de Noronha, Capim Açu (Sapata), 20/XI/1989, sobre solo arenoso da mata, O. Yano \& D.P. Costa 13631 (SP228522).

Distribuição geográfica: América Central, América do Norte, América do Sul. No Brasil: ES, MG, PR, RJ, RS, SC, SP e Ilha de Fernando de Noronha.

Comentários: Nova citação para Fernando de Noronha, porém bastante rara no local. Foi coletada apenas uma única amostra em 1989 por Yano \& Costa. Planta não encontrada durante as expedições de 2013 e 2014.

Fissidens flaccidus Mitt., Trans. Linn. Soc. London 23: 56. 1860.

Fig. 10 C-E.

Gametófitos flabelados, verde-claros a amarelados; nódulos axilares hialinos ausentes no caulídio, gemas clavadas presentes ou ausentes no caulídio. Filídios em disposição dística, lanceolados, limbídio em todo o filídio, confluente com o ápice; costa finalizando 3-15 células abaixo do ápice. Células da lâmina do filídio lisas e com paredes sinuosas, romboidais a retangulares; células da região mediana do filídio 
dispostas em fileiras paralelas com relação à costa. Esporófito não visualizado. Segundo Bordin \& Yano (2013), essa espécie apresenta esporófito terminal, cápsula cilíndrica e peristômio simples (do tipo scariosus).

Material examinado: BRASIL. PE: Fernando de Noronha, Morro do Francês, 21/XI/1989, solo no morro, $40 \mathrm{~m}$ alt., O. Yano \& D.P. Costa 13642 (SP228529); Alojamento do ICMBio, 01/XI/2013, cimento na mureta, próximo ao alojamento, $55 \mathrm{~m}$ alt., Pereira et al. 50 (UB169758); Reservatório do Pico, 02/XI/2013, rocha, 87 m alt., Pereira et al.71 (UB169780); Margem da BR, indo para Morro do Pico, 02/XI/2013, cimento, $61 \mathrm{~m}$ alt., Pereira et al. 74 (UB169782); Baia dos Golfinhos, 03/XI/2013, rocha, na trilha, 65 m alt., Pereira et al. 88 (UB169793); Capim Açu (Sapata), 04/XI/2013, tronco morto, na trilha, 159 m alt., Pereira et al. 142 (UB169847); Trilha do Abreu, 04/XI/2013, solo, de baixo de rocha, $51 \mathrm{~m}$ alt., Pereira et al. 159 (UB169864); Vila dos Remédios, 05/XI/2013, tronco morto, ao lado da igreja, $51 \mathrm{~m}$ alt., Pereira et al. 176 (UB169882); Praia do Americano, 05/XI/2013, solo, na trilha com descida para a praia, 43 m alt., Pereira et al.184 (UB169891); Trilha para Vila da Vacaria, 06/V/2014, solo, 82 m alt., Pereira et al. 304 (UB174493).
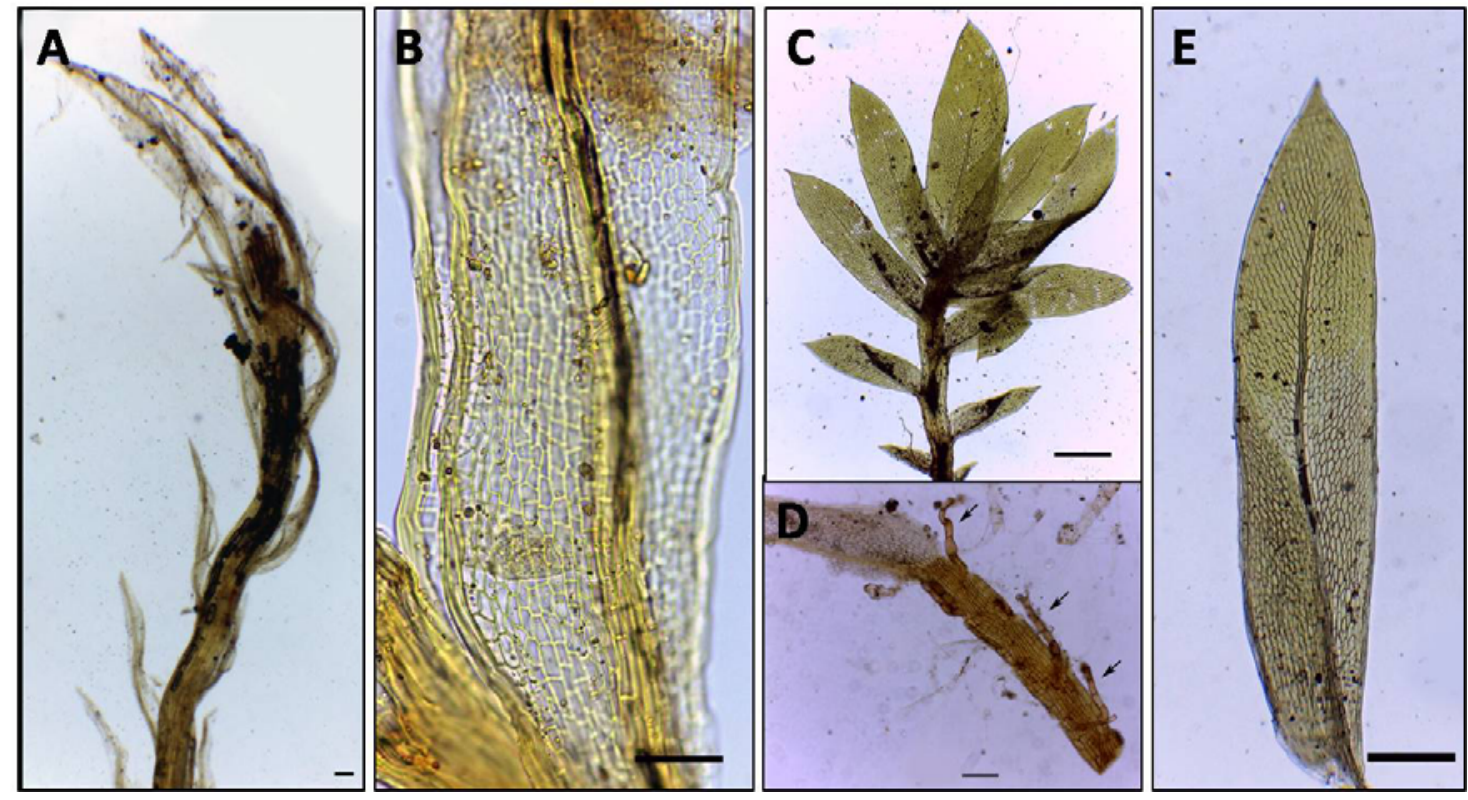

Figura 10: Fissidens curvatus Hornsch., A- Visão geral do gametófito; B- Filídio com detalhe do limbídio biestratoso (O. Yano \& D.P. Costa 13631); (C-E) Fissidens flaccidus Mitt., CVisão geral do gametófito; D- Gemas clavadas (setas) presentes no caulídio; E- Filídio (Pereira et al. 50). Escalas: A, B e D $=100 \mu \mathrm{m}$; C e E $=200 \mu \mathrm{m}$. 
Distribuição geográfica: África, América do Norte, América Central, América do Sul. No Brasil: AC, AM, BA, CE, DF, ES, GO, MA, MG, MS, MT, PA, PB, PE, PR, RJ, RO, RS, SE, SP, TO e Ilha de Fernando de Noronha.

Comentários: Nova citação para Fernando de Noronha, bastante distribuída na ilha. Facilmente encontrada durante o período de seca, Em coletas que ocorreram no período chuvoso, raramente identificou-se essa espécie. Algumas plantas apresentam papilas bem sutis, difíceis de serem visualizadas, o que dificultou bastante a identificação da espécie. Planta muito similar a Fissidens lindbergii. Pode ser diferenciada pela presença de células lisas e gemas clavadas no caulídio, algumas vezes.

Fissidens goyazensis Broth., Hedwigia 34: 120. 1895.

Gametófitos não flabelados, verde-claros a verde-escuros; nódulos axilares hialinos presente no caulídio. Filídios em disposição dística oblongo-lanceolados, com limbídio confluente com o ápice ou finalizando 6-8 células abaixo; costa percurrente a excurrente. Células da lâmina do filídio unipapilosas, irregulares, curto-hexagonais na região mediana superior e células justacostais curto-retangulares a quadráticas na base da lâmina vaginante. Esporófito não visualizado. Segundo Bordin \& Yano (2013), essa espécie apresenta esporófito terminal, cápsula cilíndrica e peristômio avermelhado simples (do tipo scariosus).

Material examinado: BRASIL. PE: Fernando de Noronha, Morro do Pico, 31/VII/1978, solo sob vegetação baixa e rala, próximo à base do Pico, D.M. Vital 8347 (SP133200); Alto Dois Abraços, 02/VIII/1978, em solo úmido, a sombra de uma árvore, D.M. Vital 8330(SP147373); Morro da Madeira, 17/XI/1989, rocha na base do morro, em frente à baia do Sueste, D.P. Costa\& O. Yano 1038 (SP228609); Baia dos Golfinhos, 03/XI/2013, rocha, na trilha para o mirante, $65 \mathrm{~m}$ alt., Pereira et al. 85 (UB169790); Praia do Sancho, 03/XI/2013, solo, próximo à trilha para praia, 64 m alt., Pereira et al. 93 (UB169798); Capim Açu (Sapata), 04/XI/2013, solo, na trilha, $159 \mathrm{~m}$ alt., Pereira et al. 110 (UB169814); Cacimba do Padre, 04/V/2014, solo, próximo à mata, 44 m alt., Pereira et al. 229 (UB174417); Trilha para Vila da Vacaria, 06/V/2014, solo, 82 m alt., Pereira et al. 303 (UB174492); Estrada velha do Sueste, indo para o Morro do Abreu, 09/V/2014, solo, 43 m alt., Pereira et al. 453 (UB174642). 
Distribuição geográfica: América do Norte, América Central, América do Sul. No Brasil: AM, BA, CE, DF, GO, MG, PB, PE, PI, RJ, SP e Ilha de Fernando de Noronha.

Comentários: Planta bastante similar à Fissidens angustifolius. A principal diferença entre estas são as células justacostais longo-retangulares na base da lâmina vaginante em F. angustifolius, enquanto que F. goyazensis apresenta células justacostais curto-retangulares ou quadráticas na base da lâmina vaginante.

Fissidens hornschuchii Mont., Ann. Sci. Nat., Bot., sér. 2, 14: 342. 1840.

Gametófitos não flabelados, verde-escuros a amarelados; nódulos axilares hialinos presentes ou ausentes no caulídio. Filídios em disposição dística, oblongolanceolados, limbídio apenas na região mediana da lâmina vaginante da maioria dos filídios, margem crenulada; costa subpercurrente. Células da lâmina do filídio unipapilosas, quadráticas a pentagonais, célula apical hialina. Esporófito não visualizado. Segundo Bordin \& Yano (2013), essa espécie apresenta esporófito terminal, cápsula cilíndrica e peristômio simples (do tipo scariosus).

Material examinado: BRASIL. PE: Fernando de Noronha, Morro da Madeira, 17/XI/1989, parede de rocha arenosa, exposta ao sol, O. Yano \& D.P. Costa 13592 (SP228509); Capim Açu (Sapata), 04/XI/2013, solo, na trilha, 159 m alt., Pereira et al. 109 (UB169813); Morro do Piquinho, 06/V/2013, solo entre rochas, na base do morro, próximo à caverna, 164 m alt., Pereira et al. 301 (UB174490).

Distribuição geográfica: América Central, América do Sul. No Brasil: AM, BA, CE, DF, ES, GO, MA, MG, MS, MT, PA, PB, PE, PI, RJ, RO, RS, SC, SP e Ilha de Fernando de Noronha.

Comentários: Fissidens hornschuchii é semelhante a $F$. lagenarius $e F$. submarginatus. Esta difere de F. hornschuchii por apresentar limbídio em toda a lâmina vaginante. Já F. lagenarius difere por não ter célula apical hialina. As células da margem F. hornschuchii apresentam projeção papilosa, o que facilita a identificação. 
Fissidens lagenarius Mitt., J. Linn. Soc., Bot. 10: 184. 1868.

Fig. 11.

Gametófitos não flabelado, verde-claros a castanhos; nódulos axilares hialinos ausentes no caulídio. Filídios em disposição dística, oblongos, limbídio apenas na lâmina vaginante dos filídios periqueciais; margem crenulada; costa subpercurrente. Células da lâmina do filídio unipapilosas, arredondadas e irregulares. Esporófito não visualizado. Segundo Bordin \& Yano (2013), essa espécie apresenta esporófito terminal, cápsula cilíndrica e peristômio simples (anômalo).

Material examinado: BRASIL. PE: Fernando de Noronha, Morro do Pico, 31/VII/1978, sobre solo úmido entre grandes rochas, próximo à base do Pico, D.M. Vital 8323 (SP147368); Morro do Piquinho, 01/XI/2013, rocha, na base do morro, 147 m alt., Pereira et al. 57 (UB169764).
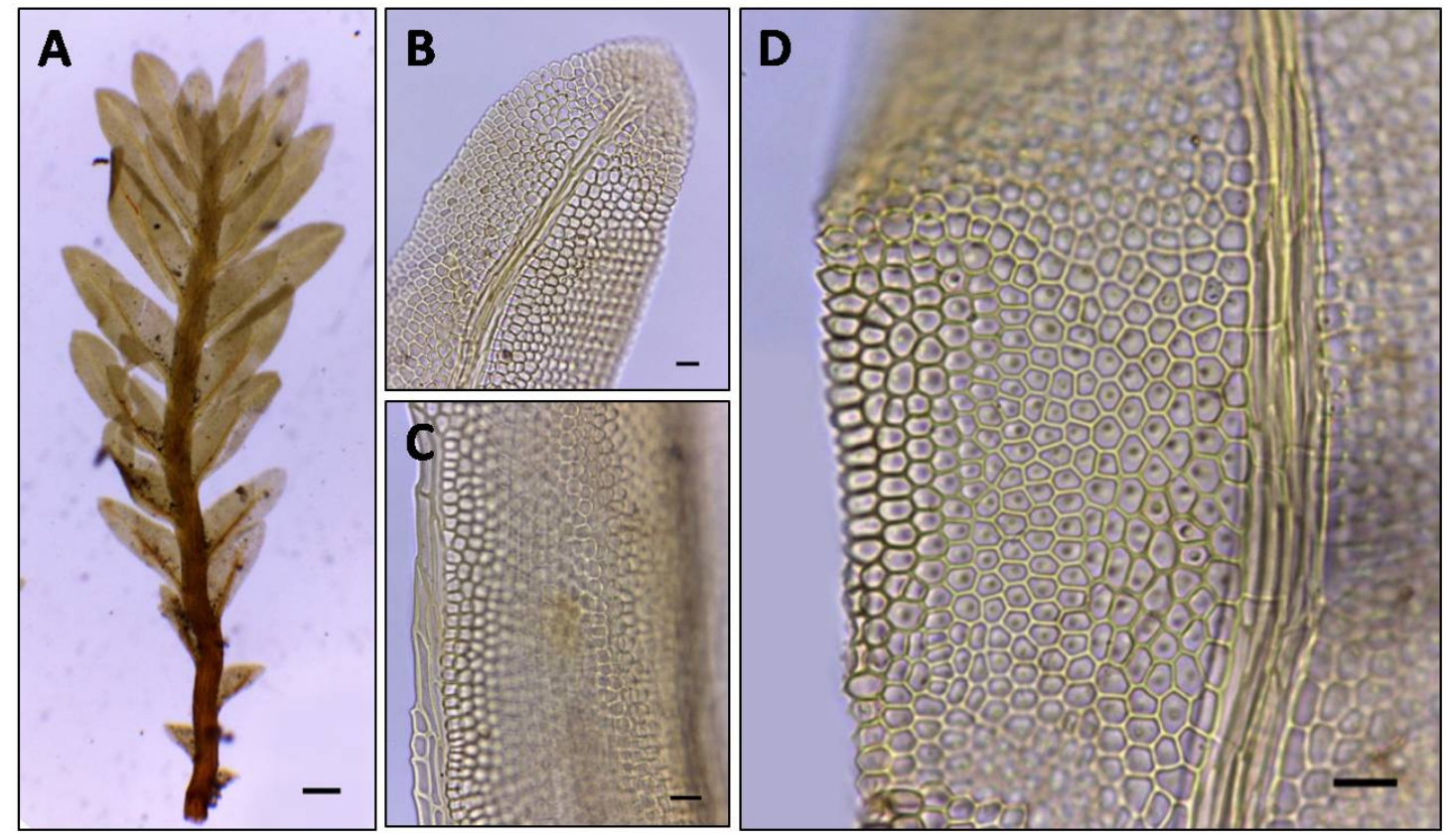

Figura 11: Fissidens lagenarius Mitt., J. Linn, A- Visão geral do gametófito; B- Ápice do filídio mostrando costa subpercurrente; C- Filídio mostrando limbídio na lâmina vaginante; D-

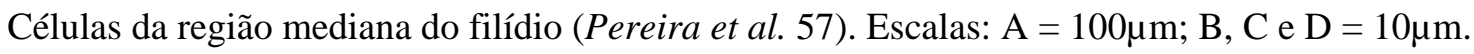

Distribuição geográfica: América Central, América do Norte, América do Sul. No Brasil: AM, CE, DF, ES, GO, MA, MG, MS, MT, PB, PA, PE, PI, PR, RJ, RS, RO, 
SC, SP e Ilha de Fernando de Noronha.

Comentários: Nova citação para Fernando de Noronha, encontrada apenas nas proximidades do Morro do Pico. A primeira amostra foi coletada em 1978, no entanto, fora identificada como sendo Fissidens hornschuchii. Demonstra similaridade com F. hornschuchii, distinguindo-se por não desenvolver célula apical hialina. Pode variar os padrões de limbídio na lâmina vaginante (Fig. 11-C) ou até mesmo não apresentá-los em plantas jovens.

Fissidens lindbergii Mitt., J. Linn. Soc., Bot. 12: 602. 1869.

Fig. 12.

Gametófitos flabelados, verde-claros a amarelados; nódulos axilares hialinos presentes ou ausentes no caulídio. Filídios em disposição dística, lanceolados, limbídio finalizando 1-3 células abaixo do ápice; costa subpercurrente, finalizando 11-18 células abaixo do ápice. Células da lâmina do filídio unipapilosas, com paredes sinuosas, irregulares, na região mediana superior hexagonais a romboidais e na região basal retangulares. Esporófito não visualizado. Segundo Bordin \& Yano (2013), essa espécie apresenta esporófito terminal.

Material examinado: BRASIL. PE: Fernando de Noronha, Vila dos Remédios, 03/VIII/1978, solo de barrancos úmidos ao sol, D.M. Vital 8342 (SP147380), como Fissidens palmatus; Forte dos Remédios, 03/VIII/1978, solo de barrancos úmidos à sombra, D.M. Vital 8340 (SP147379), como Fissidens palmatus; Alto Dois Abraços, 02/VIII/1978, solo de barrancos úmidos à sombra, D.M. Vital 8329 (SP147372), como Fissidens palmatus; Campo de Aviação, 31/VII/1978, solo úmido, junto ao campo, D.M. Vital 8328 (SP147371), como Fissidens palmatus; Baia dos Golfinhos, 03/XI/2013, rocha próximo à trilha para o mirante, $65 \mathrm{~m}$ alt., Pereira et al. 89 (UB169794); Praia do Sancho, 03/XI/2013, rocha e solo, na trilha para a praia, $64 \mathrm{~m}$ alt., Pereira et al. 98 (UB169803); Capim Açu (Sapata), 04/XI/2013, rocha, na trilha para o mirante, 159 m alt., Pereira et al. 141 (UB169791); Morro do Francês, 06/XI/2013, cimento, no chão próximo da casinha, $195 \mathrm{~m}$ alt., Pereira et al. 189 (UB169895); Trilha para a Praia do Bode, 04/V/2014, solo, na margem da trilha, $26 \mathrm{~m}$ 

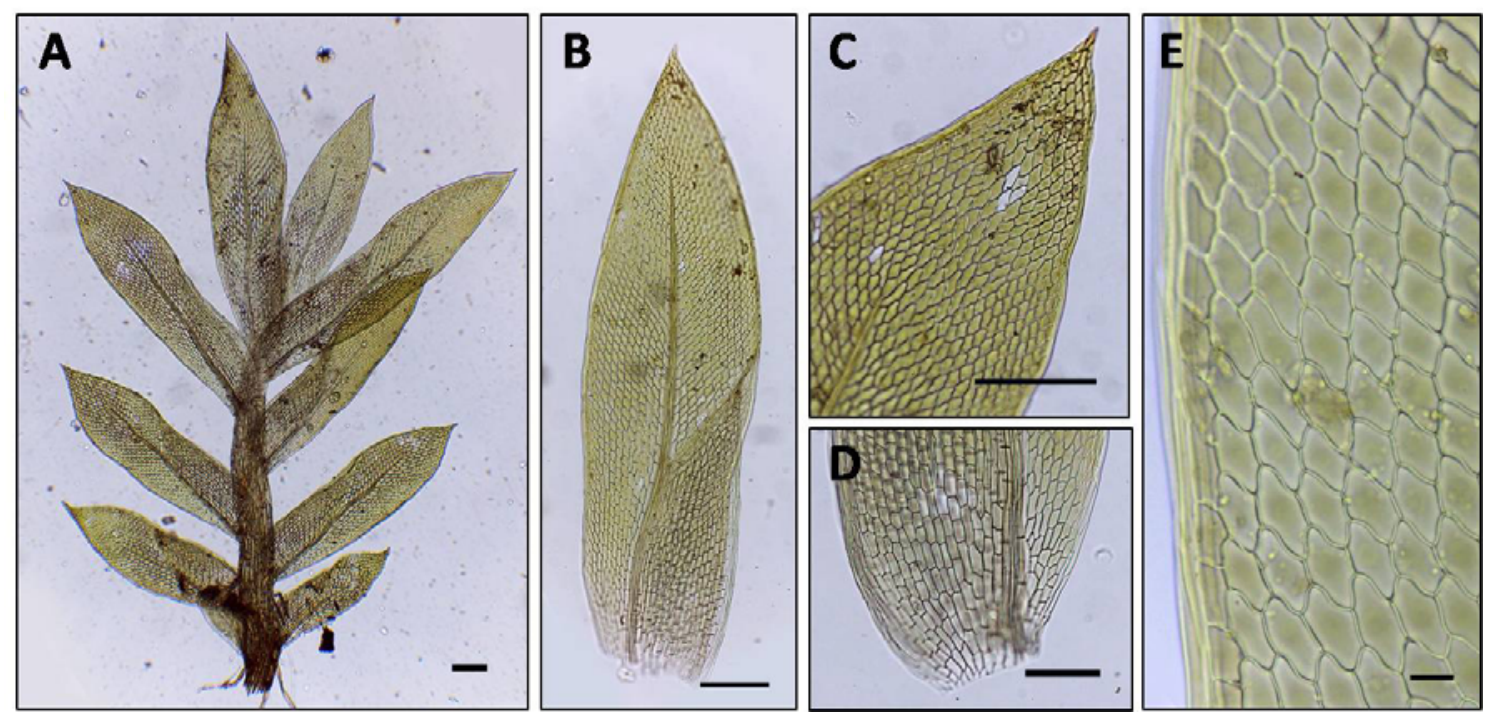

Figura 12: Fissidens lindbergii Mitt., A- Visão geral do gametófito; B- Filídio; C- Ápice do filídio; D- Base do filídio mostrando células retangulares; E- Células da região mediana do filídio (Pereira et al. 361). Escalas: A, B, C e D = 100 $\mu \mathrm{m} ; \mathrm{E}=10 \mu \mathrm{m}$.

alt., Pereira et al. 215 (UB174403); Praia do Bode, 04/V/2014, solo, próximo a um curso d’água, 29 m alt., Pereira et al. 223 (UB174411); Cacimba do Padre, 04/V/2014, cimento das ruínas da cacimba, 44 m alt., Pereira et al. 226 (UB174414); Praça Flamboyant, 05/V/2014, solo, 93 m alt., Pereira et al. 247 (UB174435); Riacho Mulungu, 05/V/2014, solo entre rochas, $60 \mathrm{~m}$ alt., Pereira et al. 277 (UB174465); Margem da BR, 06/V/2014, rocha, 80 m alt., Pereira et al. 282 (UB174471); Morro do Piquinho, 06/V/2014, rochas, na base do morro, $164 \mathrm{~m}$ alt., Pereira et al. 289 (UB174478); Trilha para a Vila da Vacaria, 06/V/2014, solo, $84 \mathrm{~m}$ alt., Pereira et al. 305 (UB174494); Praia do Leão, 07/V/2014, solo entre rochas, de frente para a praia, 25 m alt., Pereira et al. 341 (UB174530); ICMBio, 08/V/2014, solo, 55 m alt., Pereira et al. 352 (UB174540); Trilha do Atalaia, 08/V/2014, solo, 19 m alt., Pereira et al. 356 (UB174544); Estrada velha do Atalaia, 08/V/2014, rocha, $18 \mathrm{~m}$ alt., Pereira et al. 357 (UB174545); Morro da Madeira, 08/V/2014, solo, próximo à base do morro, $52 \mathrm{~m}$ alt., Pereira et al. 361 (UB174549); Trilha grande do Atalaia, 08/V/2014, solo, $81 \mathrm{~m}$ alt., Pereira et al. 378 (UB174566); Vila Quixaba, 09/V/2014, solo, 83 m alt., Pereira et al. 383 (UB174571); Farol da Sapata, 09/V/2014, solo, 185m alt., Pereira et al. 441 (UB174629); Estrada velha do Sueste, indo para o Morro do Abreu, 09/V/2014, em 
solo, 43 m alt., Pereira et al. 454 (UB174643); Morro do Abreu, 09/V/2014, em solo, 43 m alt., Pereira et al. 462 (UB174651).

Distribuição geográfica: América Central, América do Norte, América do Sul. No Brasil: BA, CE, DF, GO, PB, PE, RJ, SP e Ilha de Fernando de Noronha.

Comentários: Nova citação para Fernando de Noronha, apesar de haver amostras coletadas em 1978 e citadas por Vital et al. (1991). No entanto, estas amostras foram identificadas como sendo Fissidens palmatus.

F. lindbergii é muito semelhante a $F$. flaccidus e $F$. palmatus, em que podem ser diferenciadas por suas células lisas, já que F. lindbergii exibe papilas em suas células.

Planta encontrada freqüentemente associada à Fissidens angustifolius, Gemmabryum apiculatum, Plaubelia sprengelii e Splachnobryum obtusum, ou formando tapetes.

Fissidens palmatus Hedw., Sp. Musc. Frond. 154. 1801.

Gametófitos flabelados, verde-claros a verde-amarelados; nódulos axilares hialinos ausentes no caulídio. Filídios em disposição dística, lanceolados a oblongolanceolados, limbídio em todo o filídio, confluente com o ápice ou finalizando com algumas células abaixo; costa subpercurrente, finalizando 10-20 células abaixo do ápice. Células da lâmina do filídio lisas, hexagonais a romboidais, células da região mediana do filídio dispostas em diagonal com relação à costa. Esporófito não visualizado. Segundo o autor de sua obra princeps, esta espécie apresenta esporófito terminal, cápsula oblonga e oblíqua e opérculo rostrado.

Material examinado: BRASIL. PE: Fernando de Noronha, Praia do Sancho, 03/XI/2013, rocha, na trilha para a praia, 64 m alt., Pereira et al. 101 (UB169806); Vila dos Remédios, 05/V/2014, solo entre rochas, ao lado da igreja, $49 \mathrm{~m}$ alt., Pereira et al. 273 (UB174461); Forte dos Remédios, 03/VIII/1978, solo próximo à estrada, D.M. Vital 8341 (SP133199); Alto dois abraços, 02/VIII/1978, solo, próximo ao morro do farol, D.M. Vital 8335 (SP133197). 
Distribuição geográfica: América Central, América do Norte, América do Sul. No Brasil: AC, BA, CE, GO, MA, PE, SP e Ilha de Fernando de Noronha.

Comentários: Planta muito similar a Fissidens flaccidus, com diferenças tais como células organizadas em diagonal com relação à costa e ausência de gemas clavadas no caulídio. Esta espécie merece atenção especial, pois foi encontrada apenas em dois pontos de coleta na expedição de 2013 e em poucas quantidades.

A descrição do esporófito de F. palamatus foi encontrada apenas em sua obra princeps, não mais sendo encontrados registros na literatura recente. Porém, no trabalho de Pasiche-Lisboa \& Sastre-De Jesús (2014) amostras de solos com propágulos de F. palmatus produziram grandes quantidades de gametófitos. Assim, supõe-se que essa planta pode ter maior sucesso em reproduzir-se assexuadamente.

Fissidens submarginatus Bruch in Kraus, Flora 29:133. 1846.

Fig. 13.

Gametófitos não flabelados, verde-claros a verde-amarelados; nódulos axilares hialinos ausentes no caulídio. Filídios em disposição dística, oblongos a lanceolados, limbídio apenas na lâmina vaginante de todos os filídios; margem crenulada; costa percurrente. Células da lâmina do filídio unipapilosas, células da região mediana superior do filídio arredondadas e da região basal quadráticas a retangulares. Esporófito não visualizado. Segundo Bordin \& Yano (2013), essa espécie apresenta esporófito terminal, cápsula arredondada e peristômio simples (do tipo scariosus).

Material examinado: BRASIL. PE: Fernando de Noronha, Vila dos Remédios, 03/VIII/1978, solo, D.M. Vital 8338 (SP147377).

Distribuição geográfica: África, América Central, América do Norte, América do Sul. No Brasil: AC, AM, BA, CE, DF, ES, GO, MA, MG, MT, PA, PB, PE, PI, RJ, RN, RO, RS, SC, SP e Ilha de Fernando de Noronha.

Comentários: Espécie anteriormente citada como planta comum por Vital et al. (1991), no entanto, desde a primeira coleta em 1978, não foi mais encontrada na ilha. 
Fissidens submarginatus é bastante similar à $F$. hornschuchii, podendo ser diferenciada principalmente pela presença de limbídio em toda a lâmina vaginante, enquanto que $F$. hornschuchii apresenta limbídio apenas na região mediana da lâmina vaginante.

Em algumas plantas foi possível observar ramificações em estágios de desenvolvimento.
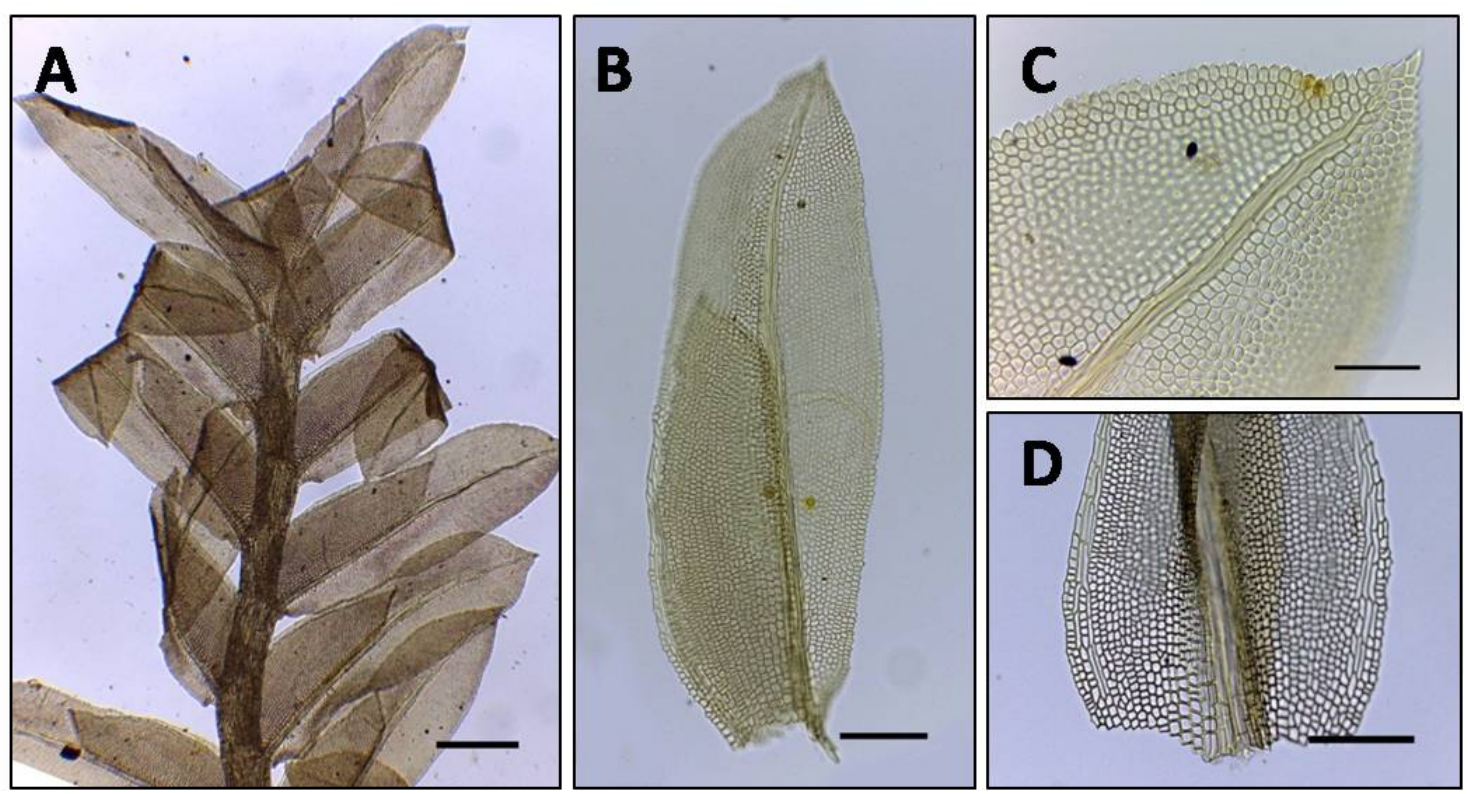

Figura 13: Fissidens submarginatus Bruch in Kraus, A- Visão geral do gametófito; B- Filídio mostrando limbídio na lâmina vaginante; C- Ápice do filídio mostrando margem crenulada e costa percurrente; D- Base do filídio (D.M. Vital 8338). Escalas: A $=200 \mu \mathrm{m}$; B e D $=100 \mu \mathrm{m}$; $\mathrm{C}=50 \mu \mathrm{m}$.

Fissidens zollingeri Mont., Ann. Sci. Nat., Bot., sér. 3, 4: 114. 1845.

Fig. 14.

Gametófitos flabelados, verde-claros a verde-amarelados; nódulos axilares hialinos presentes (bem evidentes) no caulídio. Filídios em disposição dística, oblongolanceolados, limbídio em todo o filídio, confluente com o ápice; costa percurrente. Células da lâmina do filídio lisas, células da região mediana superior arredondadas e da região basal curto-retangulares. Esporófito não visualizado. Segundo Bordin \& Yano 
(2013), essa espécie apresenta esporófito terminal, cápsula cilíndrica e peristômio simples (do tipo scariosus).

Material examinado: BRASIL. PE: Fernando de Noronha, Capim Açu (Sapata), 04/XI/2013, solo, na trilha, 159 m alt., Pereira et al. 112 (UB169816); Farol da Sapata, 09/V/2014, solo, 185m alt., Pereira et al. 438 (UB174626); Alto da Bandeira (Sapata), 04/VIII/1978, solo próximo à estrada, D.M. Vital 8346 (SP147384).

Distribuição geográfica: África, América do Norte, América Central, América do Sul, Ásia, Oceania. No Brasil: AC, AL, AM, BA, CE, DF, ES, GO, MA, MG, MS, MT, PA, PB, PE, PR, RJ, RO, RR, RS, SC, SE, SP, TO e Ilha de Fernando de Noronha.
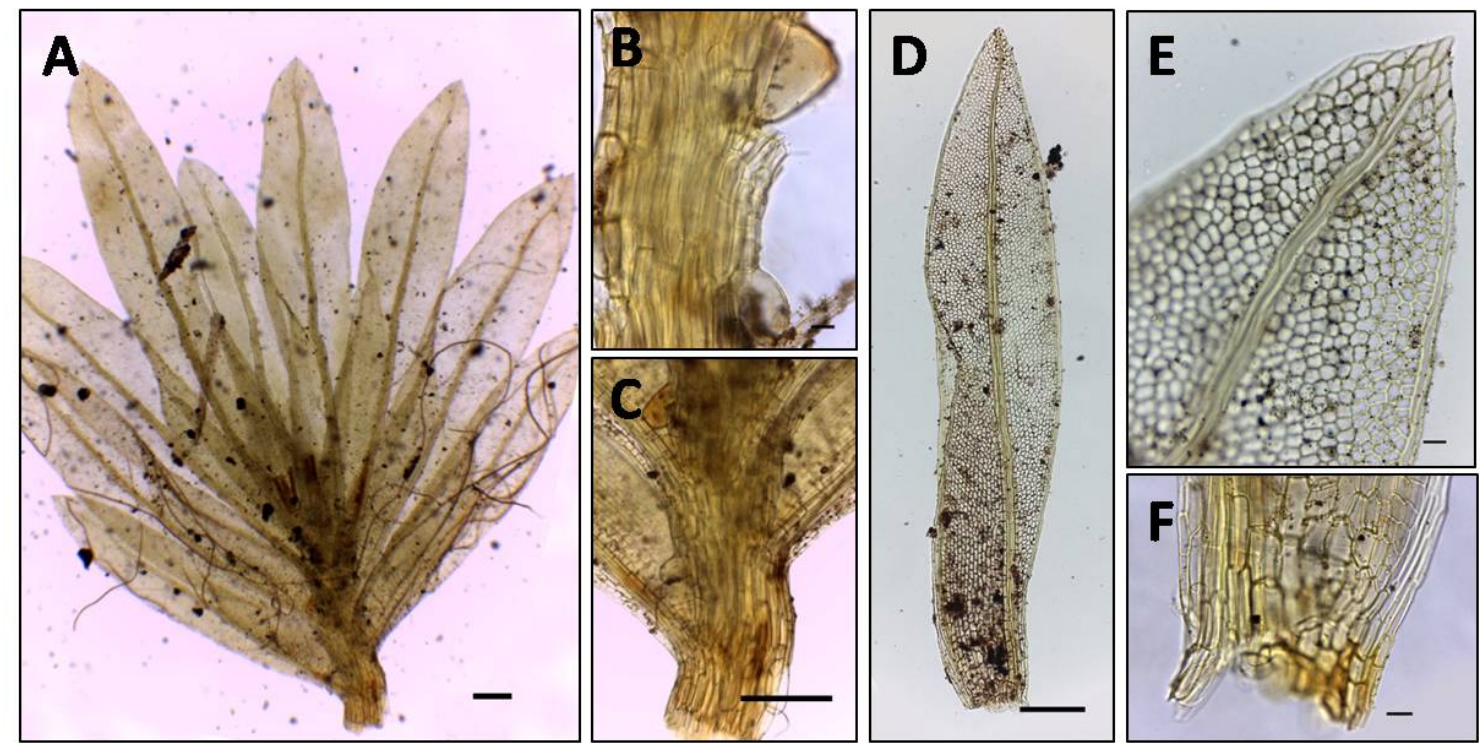

Figura 14: Fissidens zollingeri Mont., A- Visão geral do gametófito; B e C- Caulídio com nódulos axilares hialinos evidentes; D- Filídio; E- Ápice do filídio mostrando o limbídio confluente com o ápice e F- Base do filídio (Pereira et al. 112). Escalas: A e C = 100 $\mu$ m; B, E e $\mathrm{F}=10 \mu \mathrm{m}$.

Comentários: Planta considerada rara, por ser encontrada apenas na Trilha Capim Açu (Sapata). Apresenta nódulos axilares hialinos bastante evidentes, o que facilita a sua identificação em relação às outras espécies similares, como Fissidens angustifolius, F. bryoides e F. crispus. 


\section{Pottiaceae}

Hyophiladelphus agrarius (Hedw.) R.H. Zander, Bryologist 98: 372. 1995.

Gametófitos verde-claros a verde-escuros. Filídios em disposição radial, lanceolados; ápice agudo; margem revoluta; costa larga, com 6-10 células de largura, excurrente, coberta por células retangulares na superfície ventral do filídio. Células da região mediana do filídio mamilosas, isodiamétricas e células da região basal retangulares e hialinas, distinguindo-se de forma gradual das células clorofiladas, parede celular espessada. Esporófito não visualizado. Segundo Sharp et al. (1994), a espécie apresenta esporófito alongado, torcido, com cápsula cilíndrica a elipsoidal e peristômio simples e torcido.

Material examinado: BRASIL. PE: Fernando de Noronha, Vila dos remédios, 31/X/2013, cimento de muro da praça do centro comercial, 67 m alt., Pereira et al. 43 (UB169755); Morro do Francês, 06/XI/2013, cimento, na margem da estrada, 195 m alt., Pereira et al. 188 (UB169894); Mirante do Boldró, 04/V/2014, cimento, debaixo da caixa d’água, 56 m alt., Pereira et al. 242 (UB174430); Vila da Quixaba, 09/V/2014, cimento, 83 m alt., Pereira et al. 382 (UB174570).

Distribuição geográfica: América Central, América do Norte, América do Sul. No Brasil: AC, AM, BA, CE, DF, MA, MT, PA, PB, PE, RJ, RN, RO, RS, SE, SP, TO e Ilha de Fernando de Noronha.

Comentários: Espécie anteriormente citada como planta rara, com apenas uma coleta para a ilha em 1978. Nas ultimas expedições, Hyophiladelphus agrarius foi encontrada em mais lugares, freqüentemente em locais urbanizados e com incidência de luz.

Plaubelia sprengelii (Schwägr.) R.H. Zander, Bull. Buffalo Soc. Nat. Sci. 32: 176. 1993.

Gametófitos verde-claros a verde-amarelados. Filídios em disposição radial, linear-lanceolados; ápice obtuso a mucronado; margem revoluta; costa larga, com 6-10 células de largura, subpercurrente, coberta por células quadradas a arredondadas na 
superfície ventral do filídio. Células da região apical do filídio mamilosas, isodiamétricas e células da região basal retangulares, hialinas, distinguindo-se de forma gradual das células clorofiladas, parede celular espessada. Esporófito não visualizado. Segundo Sharp et al. (1994), a espécie apresenta esporófito alongado, com cápsula elipsoidal e peristômio simples.

Material examinado: BRASIL. PE: Fernando de Noronha, Vila dos Remédios, 31/X/2013, cimento, ao lado do palácio São Miguel, $54 \mathrm{~m}$ alt., Pereira et al. 15 (UB169732); Praça Flamboyant, 05/V/2014, solo, $93 \mathrm{~m}$ alt., Pereira et al. 251 (UB174439); Trilha para Vila da Vacaria, 06/V/2014, rocha, $75 \mathrm{~m}$ alt., Pereira et al. 308 (UB174494); Forte dos Remédios, 06/V/2014, cimento entre rochas, nas ruínas do forte, 63 m alt., Pereira et al. 328 (UB174517); Cemitério, 07/V/2014, cimento de túmulo, 98 m alt., Pereira et al. 333 (UB174522); Praia do Sueste, 03/VIII/1978, cimento de muro, próximo à estrada para a praia, D.M. Vital 8327 (SP147370)

Distribuição geográfica: América Central, América do Norte, América do Sul. No Brasil: AC, AM, BA, GO, MA, MG, MT, PE, RJ, RO, SP e Ilha de Fernando de Noronha.

Comentários: Espécie bastante distribuída na Ilha, encontrada freqüentemente em locais com incidência de luz direta. É muito similar a Hyophiladelphus agrarius, podendo ser diferenciada pela presença de células mamilosas no ápice dos filídios.

\section{Splachnobryaceae}

Splachnobryum obtusum (Brid.) Müll. Hal., Verh. K.K. Zool.-Bot. Ges. Wien 19: 504. 1869.

Gametófitos verde-pálidos a verde-amarelados. Filídios em disposição radial, oblongos a ligulados; côncavos; ápice obtuso; margem lisa, levemente crenulada no ápice dos filídios mais antigos; costa estreita, com 2-6 células de largura, subpercurrente. Células da lâmina do filídio lisas, células da região mediana superior hexagonais a curto-retangulares, principalmente na margem, e células da região basal hexagonais a longo-retangulares. Esporófito não visualizado. Segundo Sharp et al. 
(1994), a espécie apresenta esporófito terminal, alongado, com cápsula ereta e cilíndrica e peristômio duplo.

Material examinado: BRASIL. PE: Fernando de Noronha, Vila dos Remédios, 31/X/2013, cimento, ao lado do palácio São Miguel, $54 \mathrm{~m}$ alt., Pereira et al. 163-B (UB169869); Praia do Bode, 05/XI/2013, solo, na trilha próximo à entrada da praia, 78 m alt., Pereira et al. 183-B (UB169889); Morro do Francês, 06/XI/2013, cimento, na margem da estrada, 195 m alt., Pereira et al. 190 (UB169896); Praça Flamboyant, 05/V/2014, solo, 93 m alt., Pereira et al. 253 (UB174441); Sítio Leão, 07/V/2014, solo, no antigo viveiro de plantas, $51 \mathrm{~m}$ alt., Pereira et al. 348 (UB174536); ICMBio, 08/V/2014, solo, 55 m alt., Pereira et al. 351 (UB174539); Morro da Madeira, 08/V/2014, solo, na base do morro, 74 m alt., Pereira et al. 371 (UB174559); Vila da Quixaba, 09/V/2014, cimento, 83 m alt., Pereira et al. 382 (UB174570); Capim Açu (Sapata), 09/V/2014, solo, no estacionamento do início da trilha, $176 \mathrm{~m}$ alt., Pereira et al. 413 (UB174601);

Distribuição geográfica: África, América Central, América do Norte, América do Sul, Ásia, Europa, Oceania. No Brasil: AC, AL, AM, AP, CE, GO, MS, RS, SP e Ilha de Fernando de Noronha.

Comentários: Espécie amplamente distribuída na Ilha, encontrada principalmente em áreas urbanizadas, ocorrendo freqüentemente em associação com Fissidens goyazensis, Gemmabryum apiculatum, G. subapiculatum e Hyophiladelphus agrarius. Segundo Sharp et al. (1994), a espécie apresenta esporófito terminal, porém algumas amostras coletadas apresentaram estruturas de reprodução assexuada no ápice e nas laterais do caulídio.

\section{Stereophyllaceae}

Entodontopsis leucostega (Brid.) Buck \& Ireland, Nova Hedwigia 41: 103. 1985.

Fig. 15

Gametófitos pleurocárpicos, verde-escuros; caulídios prostrados e ramificados. Filídios lanceolados; côncavos; ápice acuminado; costa subpercurrente; região basal do 
filídio irregular entre os lados da costa. Células da lâmina do filídio lisas, longohexagonais e células da região basal quadráticas. Esporófito apresenta cápsula inclinada, ovóide, opérculo rostrado e peristômio duplo.

Material examinado: BRASIL. PE: Fernando de Noronha, Capim Açu (Sapata), 04/XI/2013, raiz de tronco vivo, na trilha, $159 \mathrm{~m}$ alt., Pereira et al. 122 (UB169826); Primeiro Mirante da Sapata, 09/V/2014, rocha, $32 \mathrm{~m}$ alt., Pereira et al. 452 (UB174641).

Distribuição geográfica: África, América Central, América do Norte, América do Sul, Ásia. No Brasil: AC, AM, BA, CE, DF, GO, MA, MG, MS, MT, PA, PB, PE, PI, RJ, RO, RR, SP, TO e Ilha de Fernando de Noronha.
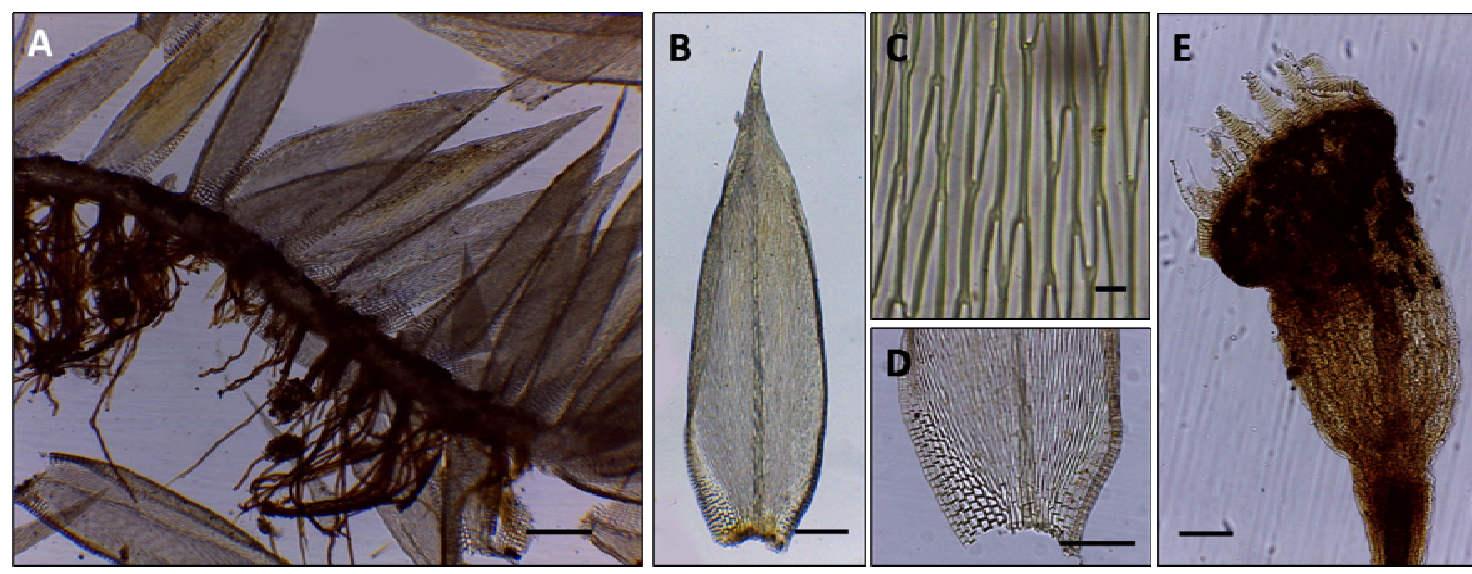

Figura 15: Entodontopsis leucostega (Brid.) Buck \& Ireland, A- Visão geral de parte do gametófito pleurocárpico; B- Filídio. C- Células da lâmina do filídio longo-hexagonais; DBase do filídio irregular entre os lados da costa; E- Cápsula com peristômio duplo (Pereira et al. 144). Escalas: $\mathrm{A}=200 \mu \mathrm{m} ; \mathrm{B}, \mathrm{D}$ e $\mathrm{E}=100 \mu \mathrm{m} ; \mathrm{C}=10 \mu \mathrm{m}$.

Comentários: Única espécie pleurocárpica encontrada na Ilha. Encontrada somente nas proximidades da trilha do Capim Açu (Sapata), é bastante distribuída neste local e ocorre formando grandes tapetes tanto em troncos e raízes de árvores vivas e em decomposição quanto em rochas de áreas mais abertas. Entondontopsis leucostega apresenta ápice do filídio acuminado, o que a diferencia de E. nitens, que tem ápice do filídio obtuso. 


\section{Discussão}

O número de briófitas listadas por Vital et al. (1991) aumentou de 22 para 28 espécies. Onze espécies são novas citações para Fernando de Noronha. Dessas, seis espécies foram identificadas a partir das amostras do Herbário SP e também a partir das coletas de 2013 e 2014, são elas: Fissidens angustifolius, F. flaccidus, F. lagenarius, F. lindbergii, Notothylas orbiculares e Philonotis cernua, e quatro espécies foram identificadas somente a partir das novas coletas: Bryum atenense, Fissidens crispus, Gemmabryum apiculatum e G. subapiculatum. A espécie F. curvatus foi identificada apenas em uma amostra do herbário SP, não sendo mais encontrada nas coletas seguintes.

Algumas espécies que antes eram citadas como sendo de ocorrência rara no trabalho de Vital et al. (1991), com apenas uma ou duas coletas, foram encontradas em mais localidades da Ilha, como é o caso de F. hornschuchii, F. zollingeri, Hyophiladelphus agrarius e Plaubelia sprengellii. Outras espécies que antes eram descritas como sendo comuns, ainda continuam sendo, Entodontopsis leucostega e Calymperes palisotii são exemplos.

De forma geral, a maioria das espécies descritas para a Ilha tem ampla distribuição no Brasil. Além de Fernando de Noronha, também estão presentes em vários estados do Brasil e ainda no México, Estados Unidos, China, Indonésia, Honduras, Venezuela, Paraguai, Bolívia, Panamá, Paraguai, dentre outros países. A brioflora de Fernando de Noronha, composta por 28 espécies, também é relativamente bem distribuída na Ilha, com exceção das espécies consideradas raras (Bryum atenense, Dicranella varia, Fissidens curvatus, F. lagenarius, F. submarginatus e Philonotis cernua), ou seja, que foram coletadas em apenas um ou dois pontos da Ilha. A distribuição restrita destas espécies na Ilha aumenta a probabilidade de extinção das mesmas, em Fernando de Noronha.

Desde a sua descoberta em 1503, o arquipélago de Fernando de Noronha vem sofrendo impactos ambientais com a ocupação antrópica desordenada. O crescimento urbano e a intensa atividade turística crescem a cada ano (Andrade et al. 2008, Serafini et al. 2010). Com isso a biodiversidade passou por profundas alterações de suas características naturais. 
É importante ressaltar que o trabalho brioflorístico realizado por Faria et al. (2012) na Ilha de Trindade indicam que o número de briófitas encontradas (32 espécies) em Trindade é maior que as encontradas (28 espécies) em Fernando de Noronha. Esses resultados são intrigantes, se forem considerados parâmetros geográficos pois como Trindade está a uma distância de aproximadamente 2 mil km do continente brasileiro, distância bem maior se comparada a do arquipélago de Noronha (545 km) e possui uma área territorial de apenas 9,8 $\mathrm{km}^{2}$ (contra $26 \mathrm{~km}^{2}$ de Noronha), o presumível era que Noronha apresentasse maior riqueza da brioflora. Essa diferença pode estar relacionada à intensa atividade antrópica, já que na Ilha da Trindade não há moradores e nem turistas. De acordo com o histórico de ocupação humana, desde 1737 a Ilha vem passando por intensa transformação, principalmente a partir de 1988, quando o potencial ambiental e turístico do arquipélago foi reconhecido (Teixeira et al 2003).

Fissidens zollingeri, F. hornschuchii e Hyophiladelphus agrarius ocorrem tanto na Ilha de Fernando de Noronha quanto na Ilha de Trindade. Apesar destas espécies serem de ampla distribuição mundial, esse dado nos é bastante interessante e, se investigado, pode trazer informações importantes para os estudos de fluxo gênico entre estas Ilhas e o continente.

Com tudo isso, medidas de preservação para Fernando de Noronha são fundamentais. Visto que Riccia ridleyi, pertencente à lista de espécies brasileiras ameaçadas de extinção (categoria CR = Criticamente em Perigo), de ocorrência para Venezuela, Peru e (Fernando de Noronha) Brasil (Gradstein \& da Costa 2003), foi localizada na Ilha no período chuvoso (coleta de 2014) formando algumas populações em pontos de visitação turística e durante o período de seca (coleta de 2013) não foi encontrada na Ilha. Outras espécies que merecem atenção são Dicranella varia e Fissidens lagenarius e F. submarginatus que foram encontradas, em apenas um local da Ilha, o Morro do Piquinho, a 150 m. de altitude, próximo ao Morro do Pico, que é um ponto freqüentado por visitantes para atividades de ecoturismo.

Cinco táxons (Fissidens elegans, F. microcladus var. pussillissimus, Notothylas vitalii, Octoblepharum albidum e Pohlia sp.), citadas por Vital et al. (1991), não foram encontradas em herbários e nem nas novas coletas de 2013 e 2014, como é o caso de $F$. microcladus var. pussillissimus, Octoblepharum albidum e Pohlia sp. No caso de Fissidens elegans e Notothylas vitalii não foi encontrada devido a identificações 
equivocadas. F. elegans foi reidentificada como F. hornschuchii e $N$. vitalii como $N$. breutelii.

Entodontopsis leucostega, Fissidens curvatus e F. zollingeri são espécies encontradas apenas nas proximidades da Trilha do Capim Açu (Sapata), um local que ainda apresenta formações florestais, com mata fechada e árvores de grande porte margeando a trilha. No entanto, esse local também é um ponto de visitação turística.

O Morro do Piquinho, e as Trilhas do Capim Açu (Sapata), Baia dos Golfinhos e Praia do Sancho são os pontos com maior diversidade e, portanto, que merecem maior atenção do Instituto Chico Mendes de Conservação da Biodiversidade - ICMBio, órgão responsável pela fiscalização e conservação do Parque Nacional Marinho de Fernando de Noronha (PARNAMAR-FN) e da Área de Proteção Ambiental de Fernando de Noronha (APA-FN). Desses pontos, o Morro do Piquinho, utilizado para atividade de escalada e rapel, e a Trilha Capim Açu (Sapata), caminho para a Caverna do Capim Açu são os mais bem preservados. Baía dos Golfinhos e Praia do Sancho são locais de intensa visitação turística.

\section{Referências Bibliográficas}

Abdala, G., (coord.) 2008. Estudo de Determinação da Capacidade de Suporte de Fernando de Noronha - Produtos 3 e 4. ICMBIO/ PNUD/ ELABORE. Brasília. 316p

Almeida, F. F. M. 1955. Geologia e Petrologia do Arquipélago de Fernando de Noronha. Rio de Janeiro: Instituto Brasileiro de Geografia e Estatística. 181p

Almeida, F. F. M.; Schobbenhaus, C.; Campos, D. A.; Queiroz, E. T.; Winge, M., \& Berbert-Born, M. L. C. 2002. Arquipélago de Fernando de Noronha-Registro de monte vulcânico do Atlântico Sul. Pp. 361-368. In: Schobbenhaus, C.; Campos D. A.; Queiroz E. T.; Winge M. \& Berbert-Born M. L. C. (eds.). Sítios Geológicos e Paleontológicos do Brasil. Brasília, DNPM/CPRM - Comissão Brasileira de Sítios Geológicos e Paleobiológicos (SIGEP) 
Anderson, L. E. 1954. Hoyer's solution as a rapid permanent mounting medium for bryophytes. The Bryologist 57: 242-244

Andrade, L.; Gomes, V. \& Borges, M. 2008. The Ecosystemic View of the Urban Occupation of Fernando de Noronha Island in Brasil. Pp 1-12. In: Ecocity World Summit 2008 - 7 th International Ecocity Conference, San Francisco: Ecocity Builders

Asakawa, Y. 2007. Biologically active compounds from bryophytes. Pure and Applied Chemistry 79(4): 557-580

Batistella, M. 1993. Cartografia Ecológica do Arquipélago de Fernando de Noronha. Instituto de Biociências da Universidade de São Paulo. São Paulo. $236 p$

Batistella, M. 1996. Espécies vegetais dominantes do Arquipélago de Fernando de Noronha; grupos ecológicos e repartição espacial. Acta Botanica Brasilica 10(2): 223-235

Bordin, J., \& Yano, O. 2013. Fissidentaceae (Bryophyta) do Brasil. Instituto de Botânica. 350 p

Castro, J. W. A. 2009. Geologia Ambiental das ilhas Oceânicas de Trindade e Fernando de Noronha, Brasil. Pp 33-53. In: Mohr L. V.; Castro, J. W. A.; Costa, P. M. S.; Alves, R. J. V.. Ilhas Oceânicas Brasileiras: da pesquisa ao manejo - volume II. Brasília: MMA/Secretaria de Biodiversidade e Florestas. 502 p

CNCFlora, Centro Nacional de Conservação da Flora. Disponível em: $<$ http://cncflora.jbrj.gov.br/> Acessado em 28/01/2015

Costa, D. P. da; Almeida J. S. dos S; Dias, N. dos S; Gradstein, S. R.; Churchil, S. P. 2010. Manual de Briologia. Editora Interciência

Costa, D. P.; Pôrto, K. C.; Luizi-Ponzo, A. P.; Ilkiu-Borges, A. L.; Bastos, C. J. P.; Câmara, P. A. E. S., Peralta, D. F.; Bôas-Bastos, S. B. V.; Imbassahy, C. A. A.; Henriques, D. K.; Gomes, H. C. S., Rocha, M. L.; Santos, N. D.; Siviero, T. F.; Vaz-Imbassahy, T. F. \& Churchill, S. P. 2011. Synopsis of the Brazilian moss 
flora: checklist, synonyms, distribution and conservation. Nova Hedwigia 93: 277-334

Crandall-Stotler, B.; Stotler, R. E. \& Long, D. G. 2009. Pp1-54. Morphology and classification of the Marchantiophyta. In: B. Goffinet \& A.J. Shaw (eds.). Bryophyte Biology. Cambridge University Press

Faria, A. L. A.; Carvalho-Silva, M.; Costa, D. P. \& Câmara, P. E. A. S. 2012. The bryophytes of Trindade Island, South Atlantic, Brazil. Acta Botanica Brasilica 26(4): 783-793

Fernández, E. G. \& Serrano, A. M. V. 2009. Atividade biológica das Briófitas. Âmbito Cultural Edições. 190 p

Gepp, A.; M. A. \& F. L. S., 1891. Musci \& Hepaticae. In: H. N. Ridley, M. A., F. L. S., Notes on the botany of Fernando de Noronha. The Journal of the Linnean Society Botany 27: 74-75

Gouveia, S. E. M.; Pessenda, L. C. R.; Ledru, M. P.; Sifeddine, A.; Menor, E. A.; Cordeiro, R. C.; ... \& Ricardi-Branco, F. S. 2005. Estudo multi/interdisciplinar em Fernando de Noronha - PE. In: X Congresso da Associação Brasileira de Estudos do Quaternário. Qual a chave para o futuro. Instituto de Geociências - USP

Gradstein, R., Churchill, S. y Salazar, N., 2001. "Guide to the Bryophytes of Tropical America”, Editorial Board, New York, EEUU. pp. 2-32

Gradstein, S. R. \& Costa, D. P. 2003. The hepaticae and anthocerotae of Brazil, In: Memoirs of the New York Botanical Garden 87: 1-273

Goffinet, B., Buck W. R. \& Shaw A. J. 2009. pp. 55-138. Morphology and classification of the Bryophyta. In: B. Goffinet \& A. J. Shaw (eds.). Bryophyte Biology. Cambridge University Press

IBGE, Instituto Brasileiro de Geografia e Estatístico. Censo Demográfico 2010. Disponível em 
<http://www.censo2010.ibge.gov.br/sinopse/index.php?dados=21\&uf=26>

Acessado em 02/04/2013

\section{ICMBio. 2013. Plano de manejo da APA Fernando de Noronha, Rocas e São Pedro}

$\begin{array}{lllll}\text { e } & \text { São } & \text { Paulo. } & \text { Disponível }\end{array}$

$<$ http://www.icmbio.gov.br/portal/images/stories/imgs-unidades-

coservacao/Resumo\%20Executivo_f.pdf> Acessado em 03/07/2013

Lista de Espécies da Flora do Brasil. Jardim Botânico do Rio de Janeiro. Disponível em: <http://floradobrasil.jbrj.gov.br/>. Acesso em: 30 jan. 2014

Köppen, W. P. 1918. Klassifikation der Klimate nach Temperatur, Niederschlag und Jahreslauf. Petermanns Geographische Mitteilungen 64: 193-203

Luizi-Ponzo, A. P. (coord.), Bastos, C. J. P., Costa, D. P., Pôrto, K. C., Câmara, P. E. S. A., Lisboa, R. C. L. \& Villas Bôas-Bastos, S. 2006. Glossarium Polyglottum Bryologiae: Versão Brasileira do Glossário Briológico. Ed. UFJF. 114 p

Markham, C. R. 2005. As quatro primeiras viagens de Américo Vespúcio: Reeditado em fac-símile e traduzida da edição original rara (Florença, 1505-6). London: B. Quaritch, 1893. In: Obras emitido pela Sociedade Hakluyt, nº 90. Traduzido com notas e uma introdução por Clements R. Markham. Disponível em $<$ http://mith.umd.edu//eada/html/display.php?docs=vespucci_letters.xml >Acessa do em 03/07/2003

Mitraud, S. F (coord.) 2001. Uso recreativo no Parque Nacional Marinho de Fernando de Noronha: um exemplo de planejamento e implementação. WWF BrasilSérie técnica 8: 17-19

Montenegro, A. A.; Ribeiro, M. R.; Montenegro, S. M.; Corrêa, M. M. \& Santos, T. E. 2009. Potencialidades hídricas superficiais de Fernando de Noronha, PE, e alternativas para incremento da oferta. Revista Brasileira de Engenharia Agrícola e Ambiental 13: 931-939

Pasiche-Lisboa, C. J., \& Sastre-De Jesús, I. 2014. Moss Propagules Banks in a Secondary Subtropical Moist Forest in Puerto Rico: A First Description. American Journal of Plant Sciences 5(09): 1394-1402 
Pessenda, L. C. R.; Gouveia, S. E. M.; Ricardi-Branco, F. S.; Ledru, M. P.; Sifeddine, A.; Menor, E .A.; Cordeiro, R. C.; Aravena, R.; Bendassoli, J. A.; Boulet, R.; Filizola, H. F.; Oliveira, S. M. B.; Ribeiro, A. S.; Freitas, A. M. M \& Saia, S. E. M. G. 2005. Dinâmica vegetacional e espacial do Mangue do Sueste, Fernando de Noronha (PE), desde o Holoceno Médio. In: X Congresso da Associação Brasileira de Estudos do Quaternário. Qual a chave para o futuro. Instituto de Geociências - USP

Reese, W.D. 1993. Calymperaceae. Flora Neotropica. Monograph 58. New York, The New York Botanical Garden. 101 p

Renzaglia, K. S. \& Vaughn, K. C. 2009. Pp: 56-139. New insights into morphology, Anatomy, development, and classification of hornworts. In: A. J. Shaw \& B. Goffinet (eds.). Bryophyte biology. Cambridge University Press

Ridley, H. N.; M. A. \& F. L. S., 1891. Notes on the botany of Fernando de Noronha. The Journal of the Linnean Society Botany 27: 1-20

Schumacker, R. (Ed.). 1985. Atlas de distribution des bryophytes de Belgique, du Grand-Duché de Luxembourg et des régions limitrophes: Anthocerotae et Hepaticae, Jardin Botanique National de Belgique. 1: 1830-1984. 41p

Sharp, A. J., Crum, H. A., \& Eckel, P., 1994. The moss flora of Mexico. Memoirs of the New York Botanical Garden 69: 1-1113

Shaw, A. J. (2009). Bryophyte species and speciation. Bryophyte Biology. Cambridge University Press: Cambridge

Serafini, T. Z., França, G. B. D. \& Andriguetto-Filho, J.M. 2010. Ilhas oceânicas brasileiras: biodiversidade conhecida e sua relação com o histórico de uso e ocupação humana. In: Revista da Gestão Costeira Integrada 10(3): 281-301

Silva Júnior, J. M. 2003. 2: 335-342. Parque Nacional Marinho de Fernando de Noronha: uso público, importância econômica e proposta de manejo. In: $\mathbf{2}^{\mathbf{o}}$ Simpósio de Áreas Protegidas - Conservação no Âmbito do Cone Sul

Silva Júnior, M. C. D.; Felfili, J. M.; Proença, C. E. B.; Brasileiro, A. C. M.; Melo 
Filho, B. D.; Silva, P. E. N. D. \& Costa, K. L. 1987. Fitossociologia da mata do Morro da Quixaba no território de Fernando de Noronha. Acta Botanica Brasilica 1(2): 257-262

Tavares, R.; de Araújo, A. P. M.; Montenegro, S. M. G. L.; Montenegro, A. A. A. \& Arruda, V. M. 2009. Abastecimento hídrico no arquipélago Fernando de Noronha-PE. XVIII Simpósio Brasileiro de Recursos Hídricos

Teixeira, W.; Cordani, U. G.; Menor, E. A.; Teixeira, M. G. \& Linsker, R., 2003. Arquipélago Fernando de Noronha: O paraíso do vulcão. São Paulo, Terra Virgem. 167p

Virtanen, R. 2014. Diaspore and shoot size as drivers of local, regional and global bryophyte distributions. Global Ecology and Biogeography, 23(6): 610-619

Vital, D. M.; Giancotti, C. \& Pursell, R. A. 1991. The Bryoflora of Fernando de Noronha, Brasil. Tropical Bryology 4: 23-24

Yano, O \& Peralta, D.F. 2007. Flora dos estados de Goiás e Tocantins Criptógamas: Musgos (Bryophyta) 6: 1-331

Yano, O. 1984. Briófitas. Pp: 27-30 In: O. Fidalgo \& Bononi V. L. R. (coods.). Técnicas de coleta, preservação e herborização de material botânico. Instituto de Botânica, São Paulo, Manual 